\title{
PREFERENCE AND PERFORMANCE OF HYPENA OPULENTA ON VINCETOXICUM ROSSICUM FOLIAGE FROM SUN VERSUS SHADE HABITATS
}

by

\begin{abstract}
Alicia Rochette
A thesis submitted to the Faculty of Graduate and Postdoctoral Affairs in partial fulfillment of the requirements for the degree of

MASTER OF SCIENCE

in

Biology
Ottawa, Ontario
January 2019

CARLETON UNIVERSITY
\end{abstract}

(C) Copyright by Alicia Rochette, 2019 


\begin{abstract}
Characteristics of individual plants from the same species can differ significantly between habitats based on abiotic factors such as light intensity and temperature. In turn, these differences in plant quality can affect herbivores that feed on the plant. Here, we examined the effects of habitat on leaf characteristics for the invasive vine Vincetoxicum rossicum, as well as the preference and performance of its biological control agent, Hypena opulenta, on sun versus shade foliage. $V$. rossicum leaves grown in sunny habitats were tougher, thicker, and had lower water content than shade leaves. $H$. opulenta larvae consumed greater amounts of shaded foliage than sun foliage and were predominately night-active. $H$. opulenta larval development did not differ between sun and shade foliage diets; however, females preferred to oviposit on sun foliage. The underlying mechanisms of these results are discussed, as well as their implications for the biological control of Vincetoxicum species.
\end{abstract}




\section{Acknowledgements}

I would first like to thank my supervisor, Naomi Cappuccino, for her continuous support, guidance, and enthusiasm for this project. She consistently encouraged me to take control of my own research and was always eager to provide feedback on my work. Working with Naomi has been a great experience, and I will always be grateful for the opportunities she has given me. I would alsolike to express my gratitude to Robert Bourchier, whose expertise and assistance was essential to this project. Furthermore, I would like to thank Sue Bertram and Thor Arnason for their input and guidance towards my research over the past couple years. Additionally, I would like to express my gratitude to Connor Woodmass and Sharla Foster for their assistance with field work for this project. A special thank you to Agriculture and Agri-Food Canada (and the Mason lab) for providing me with laboratory and rearing space to complete this project. This work was funded by the Ottawa Field-Naturalist's Club. 


\section{Table of Contents}

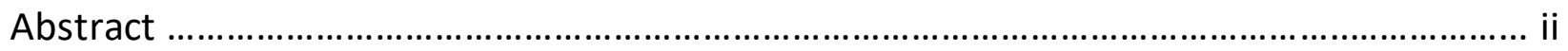

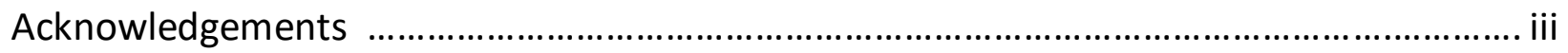

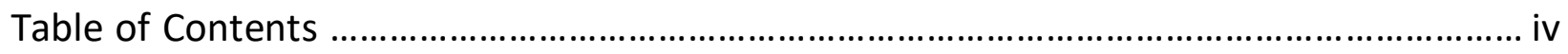

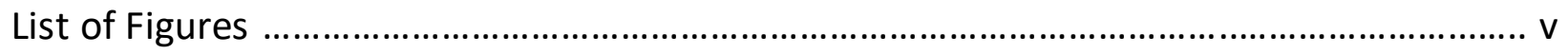

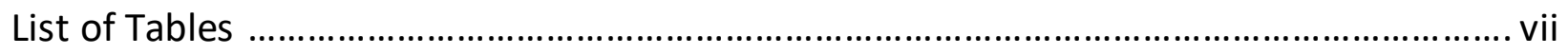

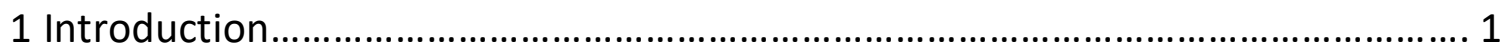

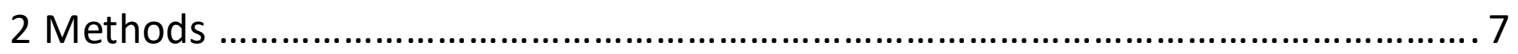

2.1 Rearing of Hypena opulenta ................................................................ 7

2.2 Foliage Collection and Field Sites ........................................................ 7

2.3 Measurements of Leaf Characteristics ................................................ 8

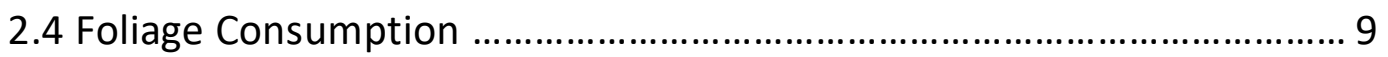

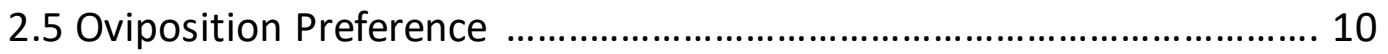

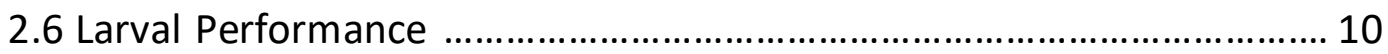

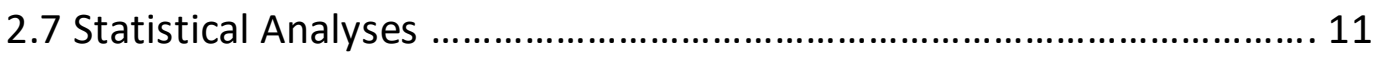

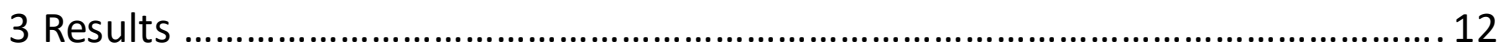

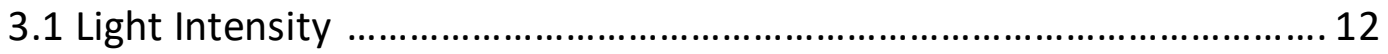

3.2 Measurements of Leaf Characteristics ……....................................... 12

3.3 Foliage Consumption .......................................................................... 13

3.4 Oviposition Preference and Larval Performance ................................. 13

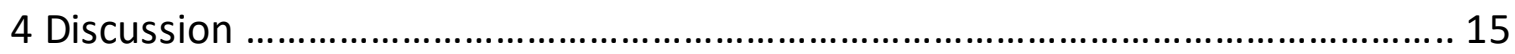

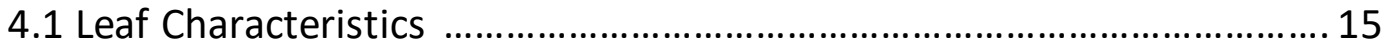

4.2 Larval Foliage Consumption ............................................................... 16

4.3 Female Oviposition Preference and Larval Performance ....................... 19

4.4 Implications to Biological Control ........................................................ 22

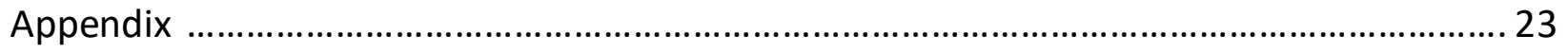

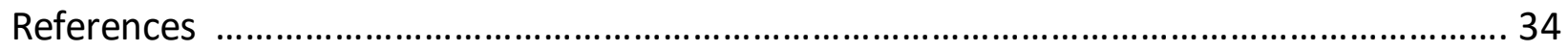




\section{List of Figures}

Figure 1 Boxplots displaying median light intensity ( $F c$ ) for Central Experimental Farm (CEF), Fletcher Wildlife Garden (FWG), and Carleton University (CU) throughout the day (data pooled over time of day for each site). Centre lines show the medians, boxes show interquartile range, and whiskers extend 1.5 times the interquartile range from the $25^{\text {th }}$ and $75^{\text {th }}$ percentiles. Asterisks within each panel indicates a significant difference in light intensity $(P<0.05)$.

Figure 2 Boxplots displaying median light intensity (Fc) for sun and shade habitats during early-, mid-, and late-day for all sites combined. Centre lines show the medians, boxes show interquartile range, and whiskers extend 1.5 times the interquartile range from the $25^{\text {th }}$ and $75^{\text {th }}$ percentiles. Asterisks with in each panel indicates a significant difference in I ight intensity $(P<0.05)$.

Figure 3 Mean \pm SE thickness $(\mathrm{mm})$ of Vincetoxicum rossicum leaves from sun and shaded habitats. Asterisks indicate significant differences in means between sun and shade foliage $(* *=<0.005)$. Sample sizes are given in parentheses.

Figure 4 Mean \pm SE leaf water content (\%) of Vincetoxicum rossicum leaves from sun and shaded habitats. Asterisks indicate significant differences in means between sun and shade foliage $(* *=<0.005)$. Sample sizes are given in parentheses.

Figure 5 Mean \pm SE specific leaf weight $\left(\mathrm{mg} / \mathrm{mm}^{2}\right)$ for sun and shade Vincetoxicum rossicum leaves during June and August 2018. Asterisks indicate significant differences in means between sun and shade foliage $(* *=<0.005)$. Letters indicate significant differences in means between June and August for sun (uppercase) and shade (lowercase) fol iage. Sample sizes are given in parentheses.

Figure 6 Mean \pm SE Vincetoxicum rossicum foliage consumption $\left(\mathrm{mm}^{3}\right)$ by Hypena opulenta larvae over a 12-hour feeding period. Larval foliage consumption was compared for larvae reared on shade and sun foliage diets, in addition to night and day feeding intervals. Asterisks indicate significant differences in means between sun and shade foliage consumption $(*=<0.05, * *=<0.005)$. Letters indicate significant differences in means between day and night for sun (lowercase) and shade (uppercase) foliage consumption. Sample sizes are given in parentheses.

Figure 7 Mean \pm SE Vincetoxicum rossicum foliage consumption $\left(\mathrm{mm}^{3}\right)$ by Hypena opulenta larvae reared on sun or shade foliage over trials spanning from July to August. Asterisks indicate significant differences in means between sun and shade foliage consumption $(*=<0.05$, $* *=<0.005)$. Letters indicate significant differences in means between early July, mid-July, and early August for sun (lowercase) and shade (uppercase) foliage consumption (Bonferroni's tests: $P<0.05$ ). Sample sizes are given in parentheses. 
Figure 8 Mean \pm SE Vincetoxicum rossicum foliage consumption $\left(\mathrm{mm}^{3}\right)$ by Hypena opulenta lanae during day and night feeding intervals between July and August. Asterisks indicate significant differencesin means between day and night foliage consumption ( $* *=<0.005$ ). Letters indicate significant differences in means between early July, mid-July, and early August for day (lowercase) and night (uppercase) foliage consumption (Bonferroni's tests: $\mathrm{P}<0.05)$. Sample sizes are given in parentheses.

Figure 9 Mean \pm SE Oviposition rate [(eggs/stem)/48 hours] for Hypena opulenta with Vincetoxicum rossicum stems grown in full-sun and shaded habitats. Asterisks indicate means are significantly different $(P<0.05)$. Sample sizes are given in parentheses.

Figure 10 Mean \pm SE larval development rate (days), measured from first instar to pupation, of Hypena opulenta reared on sun and shade foliage diets. Sample sizes are given in parentheses.

Figure 11 Mean \pm SE pupal weight $(\mathrm{mg})$ for male and female Hypena opulenta pupae reared on sun and shade foliage diets. Sample sizes are given in parentheses. 


\section{List of Tables}

Table 1 Summary of General Linear Model (GLM) (Habitat x Time x Month) on H. opulenta foliage consumption. 


\section{Introduction}

Individual plants of the same species often exhibit a range of physical and chemical differences based on abiotic factors such as light intensity, rainfall, soil composition, and temperature (Bisigato et al. 2015; Boege \& Dirzo 2004; Sarfraz et al. 2013; Uyi et al. 2017). Intraspecific variation in plant characteristics is commonly found among different light environments (Barber \& Marquis 2011; Ingersoll et al. 2010; Osier \& Jennings 2007; Wyka et al. 2012), since light intensity can directly affect the photosynthetic rate of plants, influencing morphological, physiological and biochemical processes (Mathur et al. 2018; Uyi et al. 2018; Zhang \& Wen 2009). In general, plants growing in shaded habitats are more likely to have increased foliar nitrogen (Barber \& Marquis 2011; Liang et al. 2010), increased leaf water content (Barber \& Marquis 2011; Uyi et al. 2017), thinner leaves (Hou et al. 2010; Liang et al. 2010), and reduced levels of secondary compounds (Ingersoll et al. 2010; Zhang et al. 2015) compared to plants in full-sun habitat.

Through its effect on leaf quality, light intensity also plays a key role in determining insect herbivory rates. Concentrations of secondary compounds, leaf toughness, nutrient and water content, and plant stress all contribute to the attractiveness of host plants to insects (BanfieldZanin \& Leather 2015; Bisigato et al. 2015; Malishev \& Sanson 2015). For instance, higher phenolic concentrations (e.g. tannins, glycosides) in foliage are considered to have negative effects on herbivorous insects and often reduce insect performance based on body size, survivorship, or developmental time (Dixit et al. 2017; Hwang \& Lindroth 1997; Osier \& Lindroth 
2001). Additionally, mechanical leaf properties such as leaf toughness, thickness, vein density, cuticle structures, and trichomes may be challenging for herbivorous insects, especially in younger insect stages with limited mandible strength. For example, Malishev \& Sanson (2015) determined that younger instars of the spiny leaf insect (Extatosoma tiaratum) could not penetrate leaf veins and midribs as well as older instars could; the strength to puncture tough leaf tissues was the limiting constraint in younger instars. In their experiment, larvae also performed better on foliage with lower percentages of vascular tissue, and instars of all stages preferred to feed on softer tissues located at leaf tips, suggesting that tougher leaf tissues inhibit feeding (Malishev \& Sanson 2015).

Nutrient content is also thought to play a major role in determining insect performance. Nitrogen is thought to often be the limiting nutrient for insect herbivores (Mattson 1980; Uyi et al. 2018), since many studies have shown that insects perform better on foliage with higher nitrogen content. For instance, Osier and Jennings (2007), found that foliar nitrogen content was the strongest determinant for insect performance for promethea moth (Callosamia promethea); larval mass, survivorship, and developmental rate were positively correlated with foliar nitrogen (Osier \& Jennings 2007). Similarly, foliar nitrogen was positively correlated to growth rate and larval mass in gypsy moth Lymantria dispar (Lindroth et al. 1997; Osier \& Lindroth 2001).

Interestingly, plant characteristics commonly found in shaded environments coincide with increased insect performance, suggesting that shade plants should be the preferred food choice for insect herbivores. In addition to food preference in insects, oviposition preference is equally important for determining the success of an herbivorous insect. Since many insects are too small 
to search for food upon hatching, their mother's choice of where to oviposit determines their performance. The preference-performance hypothesis predicts that females should prefer to lay eggs on foliage that correlates positively with larval success (Agosta 2006; Jaenike 1978; Potter et al. 2012). Although there are some studies that support this hypothesis (see review by Gripenberg et al. 2010), others do not (see review by Refsnider \& Janzen 2010). There are many reasons for these inconsistencies with oviposition preference. First, females may have difficulty assessing the quality of a host or site, both of which may vary over space and time (Gripenberg et al. 2007). Second, a female's decision to oviposit is subject to several considerations. She must weigh the suitability of an immediately available host against the time necessary to find a better one (and the probability of surviving until that point). Egg production constraints may also influence her choice (Potter et al. 2012). It is also important to note that female behaviours may differ greatly between laboratory and field environments or when presented with cut versus intact foliage (Friberg \& Wiklund 2016), further complicating tests of the preferenceperformance relationship.

Pale swallow-wort Vincetoxicum rossicum (Kleopow) Barbarich (Apocynaceae), also known as dog-strangling vine, is an invasive perennial vine native to Ukraine and Russia that was introduced into North America in the 1800s (DiTommaso et al. 2005). Used as an ornamental plant in botanical gardens, V. rossicum has since spread across much of northeastern North America, most notably in New York State and Ontario (Milbrath 2008). The vine produces wind-dispersed, poly-embryonic seeds, with erect stems that range from 40 to $200 \mathrm{~cm}$ in length (Casagrande et al. 2011). V. rossicum expands its range by seed, released by ripened pods in late summer, but can also expand locally by stem production from root crowns (Casagrande et al. 2011; Milbrath 
et al. 2018). V. rossicum grows in a wide range of habitats in North America, including old fields, roadsides, forest margins, forest understories, flood plains, and pastures. It tolerates a wide range of conditions, including various levels of disturbance, light, and soil pH levels (Averill et al. 2010; Milbrath et al. 2018). Once established, vines often form dense monocultures that displace native plants. $V$. rossicum is a threat for the monarch butterfly Danaus plexippus, which can mistakenly oviposit on it, resulting in larval mortality; however, the greatest threat is likely the reduction of the monarch's host plant (milkweed Asclepias spp.) through competitive displacement (DiTommaso et al. 2005).

There are few herbivores in North America that will feed on V. rossicum. Monoculture stands of V. rossicum have significantly lower arthropod abundance and diversity than native old field plants (Ernst \& Cappuccino 2005). Cattle display minimal feeding while horses, goats and sheep will avoid it (DiTommaso et al. 2005). Plant extracts of various Vincetoxicum taxa include secondary metabolites such as cardiac glycosides, flavonoids, and alkaloids that display strong antifeedant activity against some lepidopteran species (Güzel et al. 2017). Furthermore, cytotoxic phenanthroindolizidine alkaloids (such as antofine) in $V$. rossicum plants also exhibit antifungal and insect antifeedant activity (Mogg et al. 2008). The unique chemistry of $V$. rossicum is likely responsible for the success of this species in novel environments, where herbivores adapted to feed on the plant are absent (Cappuccino \& Arnason 2006).

V. rossicum has proven difficult to control. Although chemical control is an effective tool for $V$. rossicum removal, repeated herbicide applications can be costly and would negatively affect nontarget native species that are intertwined with the vine (Milbrath et al. 2016). Mechanical 
control, such as mowing, seed pod removal, or stem pulling, have only proven useful to reduce seed production but do not significantly reduce stand densities, root biomass, or aboveground biomass (Doubleday \& Cappuccino 2011; Milbrath et al. 2016). Because of this difficulty in controlling $V$. rossicum using other methods, biological control using an agent from the plant's native range may prove to be an appealing strategy for long-term suppression. In 2006, five years after a biological control program for swallow-worts was initiated, a leaf-feeding moth Hypena opulenta (Christoph) (Lepidoptera: Erebidae) was discovered feeding on $V$. rossicum and $V$. scandens in Ukraine and was subsequently studied to determine its suitability as a biological control agent (Hazlehurst et al. 2012). Extensive host-range testing revealed that $H$. opulenta was a specialist feeder on Vincetoxicum spp. (Hazlehurst et al. 2012). Additional impact assessments of herbivory by $H$. opulenta indicated that as little as two larvae per plant could reduce aboveground biomass and reproductive output of V. rossicum (Weed \& Casagrande 2010). Moths emerge in late spring to mate and then oviposit on the underside of leaves, preferentially along leaf veins. Larvae hatch within 3 to 4 days and develop over five instars (Hazlehurst et al. 2012). H. opulenta overwinter as pupae in the soil and leaf litter and have at least two generations per year (Casagrande et al. 2011). Hypena opulenta was approved for release as a biological control agent for swallow-worts in Canada in 2013 and approved for release in the United States in 2017 (Milbrath et al. 2018).

In its native range, $V$. rossicum is usually restricted to forested areas, often near rivers (Weed et al. 2011; Casagrande et al. 2011). Furthermore, H. opulenta larvae were only discovered on Vincetoxicum spp. in shaded sights even though there were stands of $V$. hirundinaria, which is a suitable host, in adjacent sunny sites only 100 metres away, suggesting that light intensity may 
affect the distribution of $H$. opulenta (Weed et al. 2011). Knowing that $V$. rossicum readily grows in sunny sites in North America where it is often found in large, dense monocultures, it is important to determine whether the biological control agent, Hypena opulenta, can successfully feed on Vincetoxicum under varying light environments.

Understanding how variations in light intensity influence leaf properties in $V$. rossicum and how its specialist herbivore $H$. opulenta responds to these changes are important for determining the success of the insect as a biological control agent. To our knowledge, there have been no studies that document the preference of $H$. opulenta for sun- or shade-grown $V$. rossicum, nor its performance on a particular foliage type. Here, we tested the hypothesis that sun and shade $V$. rossicum foliage exhibit different physical traits. We predicted that sun plants would be thicker, tougher, and have a lower leaf water content compared to shaded foliage, as is typically observed in the literature for other plants. Further, we hypothesized that $H$. opulenta prefers shade foliage rather than sun foliage, and performs better on it. We predicted that ovipositing females would lay more eggs on shade foliage and that larvae would develop faster on a shade-foliage diet and weight more at pupation. Characteristics of $V$. rossicum leaves were analyzed between sun and shade sites in the field and in laboratory, whereas the preference and performance of $H$. opulenta on $V$. rossicum was evaluated under laboratory conditions. 


\section{Methods}

\subsection{Rearing of Hypena opulenta}

Hypena opulenta pupae were overwintered in Petri dishes at $4{ }^{\circ} \mathrm{C}$ between October 2017 - May 2018. In May 2018, pupae were placed into insect cages (maximum of 40 pupae per cage) and left to emerge as adults $\left(25^{\circ} \mathrm{C}\right.$ with $16: 8$ [L:D] photoperiod). Cages were misted daily to maintain humidity. Once adults emerged, vials of $10 \%$ (wt/vol) honey-sucrose solution were provided to adults as a food source. A vase with trimmed Vincetoxicum rossicum stems (pods removed) was placed into each cage for adults to oviposit on. Once sufficient oviposition had occurred, stems were placed in water picks into transparent plastic bins $(40 \times 28 \times 17 \mathrm{~cm})$ equipped with meshlined lids (to avoid excessive moisture) and interiorly lined with paper towel. The larvae were reared at $22^{\circ} \mathrm{C}$ with $16: 8$ [L:D] photoperiod within these bins (maximum of 200 larvae per container). $V$. rossicum foliage was replaced as needed and was collected from hedgerow edges within the Central Experimental Farm, where foliage was exposed to high sun exposure in the morning, and shaded, low-light conditions in the afternoon. Larvae that were not used in experiments remained in rearing containers until they pupated; the following generation of larvae were used in subsequent experiments. All rearing was completed at the Agriculture and Agri-Food Canada (AAFC) Ottawa Research and Development Centre located in Ottawa, Canada.

\subsection{Foliage Collection and Field Sites}

V. rossicum foliage was collected at Carleton University $\left[45.383351^{\circ},-75.693000^{\circ}\right]$, Fletcher Wildlife Garden $\left[45.385446^{\circ},-75.704423^{\circ}\right]$, and the Central Experimental Farm $\left[45.388776^{\circ}\right.$, - 
$75.712697^{\circ}$ ] located in Ottawa, Canada. All three sites contained high density V. rossicum stands that included both full-sun and shaded areas in proximity to one another. Sunny habitats were exposed to full sunlight during the day, whereas shaded habitats had minimal sunlight exposure. Light intensity was measured along transects at each site and habitat with a light meter (Extech Instruments, Model \# 401027) and readings ( $n=5)$ were collected every five steps, one meter above ground level at 8:00, 13:00, and 16:00. All experiments included $V$. rossicum foliage from all three sites to ensure that any differences in foliage quality between sites were accounted for, unless otherwise stated.

\subsection{Measurements of Leaf Characteristics}

V. rossicum leaves from full-sun and shaded habitats were collected from the three sites on May 29 , June 15 , and July 26,2018 . For each collection date, 30 leaves (15 sun +15 shade leaves) per site were collected from the second node of randomly selected $V$. rossicum plants. Leaf thickness was determined from these leaves using a digital micrometer (Accusize, Model \# MD71-0001), measured at the region of the leaf between the first and second lateral veins.

Water content and specific leaf weight (SLW) were measured from leaves collected on June 8 and August 6, 2018 from all three sites. For each collection date, 10 leaves ( 5 sun +5 shade) were collected from each site, where leaves were selected using the same method previously described. A leaf punch (13.3 $\mathrm{mm}$ diameter) was used to produce leaf discs that were subsequently weighed using an analytical balance (Mettler Toldedo AG245). Weighed leaf discs were placed into coin envelopes $(6.35 \times 10.8 \mathrm{~cm})$ and oven dried at $70^{\circ} \mathrm{C}$ for 72 hours. Dried discs were weighed immediately after being removed from the drying oven. Water content (\%) was 
calculated using the formula: [(fresh weight - dry weight)/fresh weight] x $100 \%$. Specific leaf weight, used as an indicator for leaf toughness, was calculated using the formula: (disc dry weight/area of disc). Specific leaf weight is a commonly used method for estimating leaf toughness, as toughness is often positively correlated with leaf dry matter content (Steinbauer 2001).

\subsection{Foliage Consumption}

Foliage consumption trials were run at $22^{\circ} \mathrm{C}$ with a $16: 8$ [L:D] photoperiod in a rearing facility at AAFC Ottawa Research and Development Centre. GE Ecolux High Output fluorescent tubes (F54W/T5/841/ECO - 54 Watt, 4100 Kelvin) were used as the light source for this experiment. Light intensity that reached experimental plant material ranged from 3760-7535 Lux. A total of 15 sun and 15 shade stems (five of each from each site) were used per trial. Hypena opulenta larvae ( $4^{\text {th }}$ instars) were placed individually into 30 insect cages with a single stem. Insect cages were composed of a bamboo stick (trimmed to size), with a water pick taped to it. A microperforated clear plastic bag was placed around the bamboo stick and water pick, and tied at the top with twine rope. Trials were 12 hours in duration and were conducted either during the day (08:00-20:00) or night (20:00-08:00). Both day and night trials were conducted in early July, midJuly and early August 2018, where foliage consumption over a 12-hour period for each larva was recorded. Some larvae did not feed during a trial because they were molting; these individuals were excluded from further analysis. Leaves with larval feeding damage were scanned, and scans were converted into a JPEG file for measurement of leaf area and area consumed using ImageJ (version 1.52g; NIH, Bethesda, Maryland). Leaf area and average leaf thickness (values varied 
depending on site and habitat) were combined to determine the actual consumption per larva

using the formula: Surface area $\left(\mathrm{mm}^{2}\right) \times$ thickness $(\mathrm{mm})=$ total consumption $\left(\mathrm{mm}^{3}\right)$. Each trial began with a new set of $4^{\text {th }}$ instar $H$. opulenta larvae and freshly cut $V$. rossicum stems.

\subsection{Oviposition Preference}

Newly emerged $H$. opulenta moths (18 males, 18 females) were transferred into a large cage supplied with a $10 \%$ sucrose vial. Three sun and shade $V$. rossicum stems (collected at random from any of the given sites) were placed into the cage for 48 hours to ensure sufficient oviposition. The number of leaves per stem used in this experiment were matched so that each treatment had comparable surface areas for oviposition. Stems were removed after 48 hours and the number of eggs on each stem were counted. This experiment was repeated five times using the same moths between August 1-11, 2018.

\subsection{Larval Performance}

First instar $H$. opulenta larvae were placed into individual petri dishes $(n=40)$ lined with paper towel. Half of the larvae were provided a shade foliage diet $(n=20)$, and the other half a sun foliage diet $(n=20)$. Foliage was collected from all three sites at random for the duration of the experiment. Petri dishes were cleaned as needed and larvae were provided with one $V$. rossicum leaf daily (either a sun or shade leaf depending on diet type). The number of days taken to develop from first instar larva to pupa was recorded. Additionally, H. opulenta pupae were sexed under a microscope and weighed for both treatments. 


\subsection{Statistical Analyses}

Independent-samples t-tests were used to the determined the effect of habitat on leaf thickness and water content. The effect of habitat and time on specific leaf weight were analyzed by using a General Linear Model (GLM). To satisfy the assumptions of normality and homogeneity of variance, the data collected for leaf thickness and specific leaf weight were log-transformed for the analysis. The effect of habitat type, time of day, and month on the outcome of larval foliage consumption was analyzed using a GLM. Post-hoc tests with Bonferroni correction were applied to the analysis. Site was initially incorporated into all models where the variable was applicable, however it was dropped from the final models due to non-significance. Oviposition rate was compared between sun and shade foliage using an independent-samples t-test. Larval development between sun and shade foliage diets were also compared using an independentsamples t-test. The effects of sex and diet type (sun vs. shade foliage) on pupal weight was determined using a GLM. All statistical analyses were performed using IBM SPSS version 25 (SPSS, Chicago, IL, USA). The assumptions of normality and the homogeneity of variance were met unless otherwise stated. 


\section{Results}

\subsection{Light Intensity}

Measures of light intensity were significantly different between selected sun and shade habitats for all three field sites (Mann-Whitney $U=0, n_{1}=n_{2}=15, P<0.0001$ for Central Experimental Farm (CEF), Fletcher Wildlife Garden (FWG), and Carleton University sites (CU); Figure 1). Furthermore, light intensity remained significantly different throughout the day (Mann-Whitney $\mathrm{U}: \mathrm{U}=0$, $n_{1}=n_{2}=15, P<0.0001$ for 8:00, 13:00, and 16:00; Figure 2).

\subsection{Measurements of Leaf Characteristics}

Habitat had a significant effect on the thickness of $V$. rossicum leaves (independent-samples $t$ test: $\left.\mathrm{t}_{(268)}=14.763, \mathrm{P}<0.0001\right)$; Vincetoxicum rossicum leaves growing in the sun were approximately $25 \%$ thicker than leaves growing in shaded habitat (Figure 3 ). Furthermore, shaded foliage had significantly higher leaf water content compared to sun foliage $\left(t t_{(58)}=-6.964\right.$, $\mathrm{P}<0.0001 ;$ Figure 4). Neither site nor month contributed significantly to preliminary models, so these predictor variables were omitted from the analysis.

Specific leaf weight (SLW, in $\mathrm{mg} / \mathrm{mm}^{2}$ ) differed significantly between sun and shade foliage (GLM:

$F(1,56)=249.288, P<0.0001$; Figure 5). Additionally, SLW was affected by month $(F(1,56)=9.394$, $P=0.003)$. There was a significant interaction between month and habitat type $\left(F_{(1,56)}=7.395\right.$, $\mathrm{P}=0.009$ ). Sun foliage exhibited higher SLW that increased as the season progressed, whereas shade foliage did not change over time (Figure 5). 


\subsection{Foliage Consumption}

Time of day (GLM: model $F=16.242, P<0.0001 ; F_{(1,240)}=103.47, P<0.0001$ ) and habitat type $\left(F_{(1,240)}=17.45, P<0.0001\right)$ had significant effects on larval foliage consumption; Hypena opulenta larvae consumed higher amounts of shade foliage than sun foliage, and also increased consumption of all foliage at night (Figure 6). There was a slight interaction between habitat and time of day on foliage consumption $\left(F_{(1,240)}=4.76, P=0.03\right.$; Figure 6$)$, where larvae feeding on shade foliage increased consumption considerably more between day and night intervals compared to larvae on sun foliage diets. Consumption varied significantly for trials between July and August $\left(F_{(2,240)}=15.86, P<0.0001\right.$; Figure 7$)$; however, there was no interaction between habitat and month $\left(F_{(2,240)}=1.68, P=0.188\right)$. There was a significant interaction between time of day and month $(F(2,240)=6.06, P=0.003$; Figure 8$)$; both day and night feeding consumption increased as the season progressed, however night feeding increased more drastically. A preliminary analysis indicated that there was no effect of site on consumption therefore this variable was omitted from the analysis.

\subsection{Oviposition Preference and Larval Performance}

H. opulenta adults had a higher oviposition rate [(eggs/stem)/48 hours] on sun stems compared to shade stems (independent-samples t-test: $\mathrm{t}_{(8)}=2.56, \mathrm{P}=0.034$; Figure 9). Larval development from first instar to pupa did not differ between sun and shade foliage diet types (independentsamples t-test: $\mathrm{t}_{(36)}=1.14, \mathrm{P}=0.26$; Figure 10$)$. Furthermore, pupal weight was not affected by diet type (GLM: $F_{(1,34)}=0.292, P=0.593$; Figure 11 ), nor was pupal weight significantly affected by sex 
$(F(1,34)=2.44, P=0.128)$. There was no interaction between diet type and sex on pupal weight $\left(F_{(1,34)}=0.006, P=0.936\right)$. 


\section{Discussion}

In this study, we examined the effect of light intensity on invasive Vincetoxicum rossicum foliage to determine how different foliage types could influence the preference and performance of its biological control agent, Hypena opulenta. Here we show that $V$. rossicum plant traits varied between sun and shade foliage, which subsequently affected the feeding behaviour and oviposition preference of H. opulenta.

\subsection{Leaf Characteristics}

Variation in light intensity significantly affected several $V$. rossicum plant traits between full-sun and shaded habitats. For instance, leaves grown in shaded habitats were thinner and had reduced specific leaf weight (SLW; a measurement commonly used to indicate leaf toughness - see Steinbauer 2001), and increased water content. Interestingly, sun foliage became significantly tougher as the season progressed, but shaded foliage did not. This may suggest that sun leaves become less palatable to insect herbivores over time, as leaf toughness generally decreases foliar quality (Feeny 1970; Malishev \& Sanson 2015). For instance, Feeny (1970) analyzed the performance of winter moth Operophtera brumata larvae on either mature or young oak leaves and found that larval weights were significantly higher on young, tender foliage rather than tougher, mature foliage. Similarly, larval and pupal mortality of mustard beetle Phaedon cochleariae increased with increasing leaf toughness on Brassicaceae spp. (Tanton 1962). Typically, leaves become tougher and thicker over the growing season from the deposition of carbon-based plant materials (Feeny 1970), however we found that toughness increased over the season for sun foliage only. Water content was significantly higher in shade plants, likely due 
to differences in the transpiration rate, leaf surface area, and temperature between sun and shade foliage and their respective environments (Smith \& Nobel 1977). Differences in chemical composition between sun and shade $V$. rossicum leaves (i.e. nitrogen, carbon, secondary metabolites) were not measured in this study, so we do not know if the $\mathrm{C} / \mathrm{N}$ ratio is higher in sun plants as it often is (e.g., Steopler \& Rehill 2012), thus speculation cannot be made on this subject. Overall, the differences between sun and shade foliage in this study are consistent with results from other studies that have analyzed sun and shade leaf traits (e.g., Barber \& Marquis 2011; Stoepler \& Rehill 2012; Uyi et al. 2017).

\subsection{Larval Foliage Consumption}

Consumption rates were considerably different between foliage from sun and shade habitats; $H$. opulenta larvae fed significantly more when provided a diet of shade leaves. This could suggest that tougher sun foliage is more challenging to consume than shade plants as larvae may take longer to chew through tougher leaf veins, resulting in a lower rate of leaf consumption. A similar outcome was found in a study by Raupp (1985), where leaf beetles Plagiodera versicolora reared on a diet of tough Salix spp. leaves had higher mandibular wear and consequently reduced feeding rates compared to beetles on tender leaves. In contrast, our results may also suggest that H. opulenta consumes more shade foliage because it is a lower quality food source. Insect herbivores may feed more on low-quality food to obtain the same amount of nutrients required

for successful development, otherwise known as compensatory feeding (Simpson \& Abisgold 1985). Migratory locusts Locusta migratoria reared on artificial diets that varied protein and carbohydrate levels (low vs. high) compensated for lower nutrient levels by consuming more of 
that diet (Simpson \& Abisgold 1985). Insects may modify their feeding behaviour between different types of foliage; however, trade-offs may arise for compensatory feeding between nutrient and secondary metabolite ingestion. For instance, Slansky \& Wheeler (1992) modified diets with progressively diluted concentrations of nutrients yet maintained the concentration of caffeine (methylxanthine alkaloid) for all diets. They found that velvetbean caterpillars Anticarsia gemmatalis, compensated for diluted nutrient diets by increasing consumption, and in turn ingested a higher amount of caffeine that resulted in reduced survivorship and growth rate (Slansky \& Wheeler 1992). Although we do not know the chemical composition for sun and shade V. rossicum foliage, it is possible that nutrients are more diluted in shade plants (from higher water content), resulting in compensatory feeding for Hypena opulenta larvae. Environmental factors not considered in this study such as soil moisture, plant age, and temperature may also influence $V$. rossicum foliage quality and in turn, its effect on $H$. opulenta herbivory.

Antofine, an alkaloid found in $V$. rossicum plants, has been thought to exhibit mild phototoxic activity (J.T. Arnason, pers. comm.), which may partially explain the feeding behavior of $H$. opulenta larvae. For instance, Chrysolina hyperici larvae that feed on St. John's-wort Hypericum perforatum have increased mortality with increasing light intensity, due to the phototoxic compound hypericin. These larvae therefore avoid sunlight by burrowing in the soil during the day, and emerge at dawn to feed (Fields et al. 1989). Similarly, H. opulenta have only been discovered on shaded foliage in their native range (Weed et al. 2011), and results from this study indicate that larvae have the highest herbivory rate on shaded foliage between 20:00-08:00 (i.e. night trials). Furthermore, $H$. opulenta larvae of all ages are commonly found feeding on the 
underside of leaves, away from direct sunlight (pers. obs.). It is possible that these behaviours are adaptations to minimize phototoxicity, however more work is needed on this subject.

Larvae fed significantly more during the night, suggesting that this species is primarily night active. This is not surprising since many lepidopteran larvae are nocturnal to avoid higher levels of predation associated with daytime (Berger and Gotthard 2008). To our knowledge, this is the first study that has observed a nocturnal feeding tendency in Hypena opulenta larvae, however further study is needed on their feeding behavior to determine whether or not they are a nocturnal species. There appeared to be an increase in overall foliage consumption (especially on shade foliage) by $\mathrm{H}$. opulenta larvae as the season progressed; younger, developing leaves are generally valued as a higher quality food source than mature, late-season foliage (Feeny 1970; Lowman 1985; Mazía et al. 2012; Riipi et al. 2002; Zehnder et al. 2009). Leaf cell walls do not lignify until they are fully mature; therefore, expanding leaves lack toughness. Because of this, plants will often invest more in the chemical defense of young leaves compared to mature leaves (Brunt et al. 2006; Wiggins et al. 2016). Many studies have observed young leaves with higher levels of secondary metabolites (e.g., Brunt et al. 2006; Coley 1983; Mazía et al. 2012; Wam et al. 2017; Zhender et al. 2009), however this trend varies depending on the type of secondary chemicals being studied (Riipii et al. 2002). Expanding leaves are also higher in nitrogen and proteins than mature leaves, further suggesting that younger leaves are more suitable for insect herbivores (Feeny 1970; Zhender et al. 2009). Additionally, it has been noted that Hypena opulenta larvae frequently feed on the upper portion of $V$. rossicum plants, where the newly expanded leaves are located (Casagrande et al. 2011). 


\subsection{Female Oviposition Preference and Larval Performance}

Larval performance of $H$. opulenta, based on development time and pupal weight, did not differ between sun and shade foliage diets. From the perspective of biological control, this is a promising result, which suggests that development of $H$. opulenta will not suffer in shady habitats as a consequence of poor food quality. However, since temperature and humidity are alsolikely to influence larval development rate in shady versus sunny habitats, it remains to be seen how the direct effect of these abiotic habitat differences (Carrington et al. 2013, Johns et al. 2012) will affect $H$. opulenta development in the field.

Interestingly, females preferred to oviposit on $V$. rossicum stems grown in sunny habitats. This was unexpected; H. opulenta larvae are only found on shaded Vincetoxicum foliage in their native environment (Weed et al. 2011), suggesting that females must only oviposit within shaded sites, or that survivorship is much lower for larvae in sunny sites. Sun plants were much thicker than shaded plants and had distinctly larger leaf veins on the underside of leaves. Knowing that females prefer to lay along leaf veins, it is possible that the larger grooves along sun foliage leaf veins are preferable for oviposition. Eggs were also less conspicuous when located beside larger leaf veins rather than small veins (pers. obs.), which may afford protection against egg predators or parasitoids. In many species, female host plant preference correlates positively with larval performance (Gripenberg et al. 2010). Newly hatched larvae have limited mobility and usually remain on the plant that they hatched on, so it would be beneficial for females to select suitable host plants for their offspring. In contrast, many examples of females selecting host plants that are nutritionally inferior have been recognized (see review by Refsnider \& Janzen 2010). Females 
may select oviposition sites that do not directly improve larval development, but instead minimize predation, parasitism or intraspecific competition for their offspring. For example, parasitism rates on Euclea delphinii and Acharia stimulea, were significantly higher in sunny sites compared to shaded sites (Stoepler \& Lill 2013). Stoepler \& Lill (2013) determined that there were trade-offs for larvae in both sun and shade habitats; sunny sites resulted in higher parasitism rates, increased larval performance, and increased physiological challenges (e.g., heat stress), whereas larvae in shade exhibited the opposite (Stoepler \& Lill 2013). As a result, ovipositing females of these two species utilize both habitat types; however, their habitat use likely varies depending on parasitoid pressure (see also Diamond \& Kingsolver 2010). Parasitism cues affect the oviposition strategy of seed beetles Mimosestes amicus; if the distribution of parasitized eggs is relatively high, seed beetles will either stack eggs (reducing parasitismfor eggs near the bottom of the stack) or avoid ovipositing altogether, suggesting that insects can effectively shift their oviposition behaviour based on environmental cues (Deas \& Hunter 2013).

Plants growing within sunny habitats have an increased photosynthetic rate, thereby increasing the production of carbon-based compounds such as tannins, lignins, and phenols (Bryant et al. 1983; Yang et al. 2018; Zhang et al. 2015). In contrast, shaded plants exhibit a lower photosynthetic rate, a lower $\mathrm{C} / \mathrm{N}$ ratio and proportionally higher levels of nitrogen-based defensive compounds such as alkaloids (Bryant et al. 1983). It is possible that females of some species may select sunny sites for oviposition to increase the sequestration of carbon-based chemical compounds by their offspring; alternatively, shady sites might be chosen in a species that sequesters nitrogen-based secondary compounds. It has been noted that gypsy moth larvae Lymantria dispar reared on foliage with increased levels of phenolic glycosides were less 
palatable to black-capped chickadees (Poecile atricapilla) than larvae that were not as chemically defended (Müller et al. 2006). Similarly, predator avoidance was higher in arctiine moths Utetheisa ornatrix that were reared on Crotalaria spp. with higher levels of pyrrolizidine alkaloids (Martins et al. 2015). A meta-analysis conducted by Zvereva et al. (2016) determined that chemical defenses sequestered by specialist herbivores were more effective against predators than those of generalist species. It is possible that the specialist herbivore $H$. opulenta utilizes plant-derived chemicals as a means to minimize predation. Although there is limited research regarding the sequestering ability of $H$. opulenta, we do know that $H$. opulenta does not sequester antofine (a phenanthroindolizidine alkaloid) from its host plant (unpublished data).

Females of some species may select oviposition sites based on the level of inter- and intraspecific competition in their environment. In some studies, females tend to prioritize uninfested host plants or host plants that contain heterospecific competitors rather than conspecifics for oviposition site selection, which is likely to reduce the likelihood of attracting natural enemies thereby increasing offspring survival (Amiri-Jami et al. 2016; Rausher 1979; Shiojiri et al. 2015).

Although laboratory studies are a useful tool for determining $H$. opulenta preference and performance between sun and shade foliage, further work should include field studies for larval development and oviposition preference of Hypena opulenta. Environmental factors such as temperature, humidity, and predation pressure as well as differences between intact versus cut foliage (see Friberg \& Wiklund 2016) will provide useful information on how this biological control agent performs in the field. Future studies should also include chemical analyses between sun and shade foliage for $V$. rossicum, as there is little information on this subject. Furthermore, 
assessing the feeding behaviour of $H$. opulenta larvae, using early-, mid-, and late-season foliage in field experiments would be beneficial for determining the effectiveness of this biological control agent.

\subsection{Implications to Biological Control}

Our results suggest that $H$. opulenta larvae can develop equally on sun and shade foliage, thus mass-rearing on either sun or shade foliage would be suitable. For optimal female oviposition, thicker sun foliage should be used rather than shaded foliage to increase oviposition rate. When conducting artificial defoliation on V. rossicum plants, Milbrath (2008) determined that plants growing under low-light conditions were more negatively affected by defoliation than plants growing under high-light conditions; repeated defoliation trials were required to reduce seed production, aboveground and root biomass of $V$. rossicum under high-light conditions, whereas only one round of artificial defoliation was needed for low-light plants. Although $V$. rossicum plants are tolerant to moderate $H$. opulenta defoliation, shade plants are usually less tolerant and more likely to reduce seed output and biomass under larval defoliation (Milbrath \& Biazzo 2016). This, coupled with the tendency for $H$. opulenta to consume more shade foliage, suggests that $H$. opulenta may be most effective at controlling $V$. rossicum stands in shaded habitats. To our knowledge, our study is the first to determine the feeding behaviour and oviposition preference of $H$. opulenta; however, field studies are needed to determine the feeding behaviour and development of $H$. opulenta in a more realistic environment. Hypena opulenta may prove to be a promising biological control agent for Vincetoxicum spp. once successful establishment occurs across North America. 


\section{Appendix}

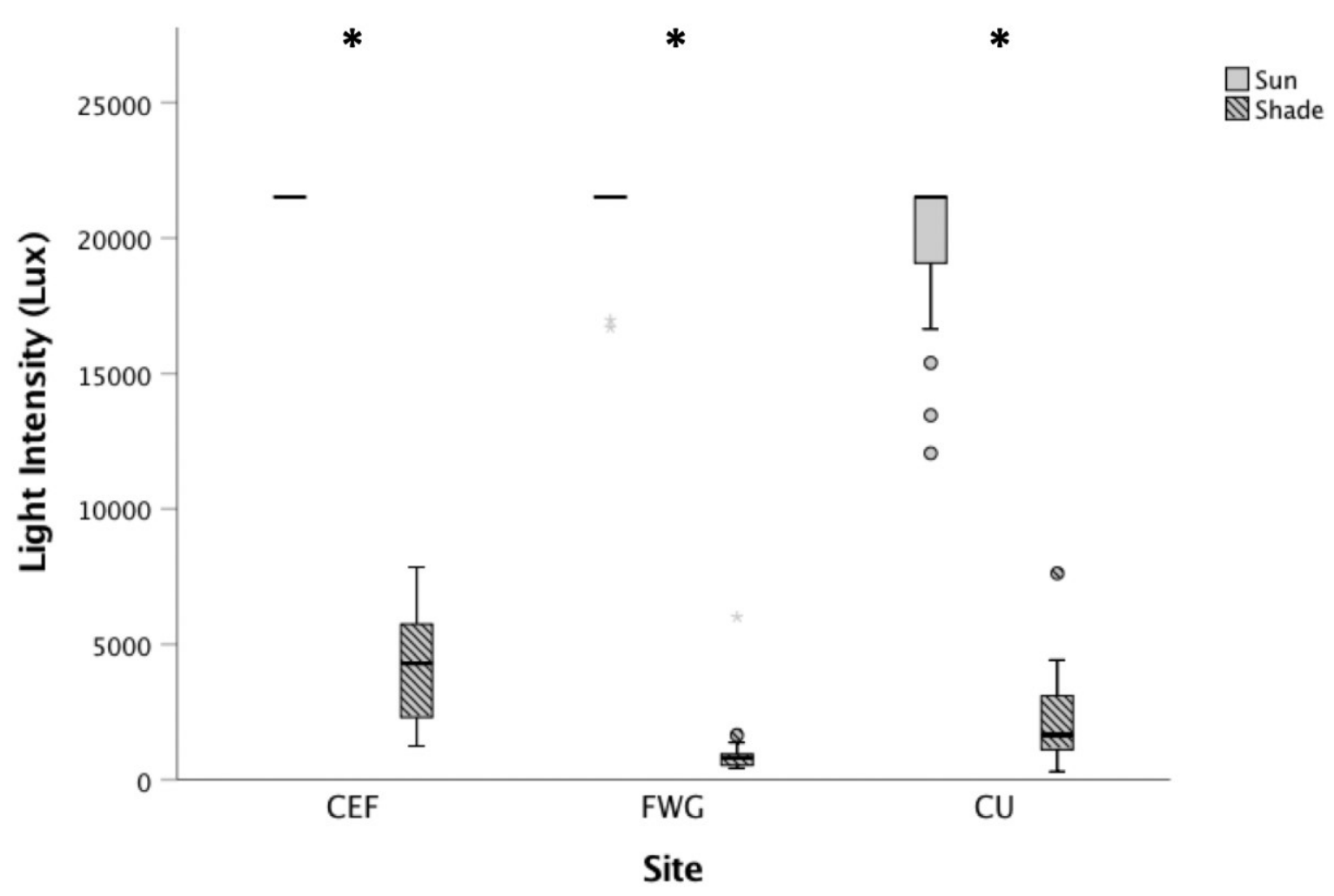

Figure 1 Boxplots displaying median light intensity (Lux) for Central Experimental Farm (CEF), Fletcher Wildlife Garden (FWG), and Carleton University (CU) throughout the day (data pooled over time of day for each site). Centre lines show the medians, boxes show interquartile range, and whiskers extend 1.5 times the interquartile range from the $25^{\text {th }}$ and $75^{\text {th }}$ percentiles. Asteris ks within each panel indicates a significant difference in light intensity $(P<0.05)$. Note: The light meter had a maximum reading of $\sim 21,500$ Lux (i.e. 2,000 Foot-candles), therefore measurements recorded in sun habitats shown above are likely smaller than the actual value. 


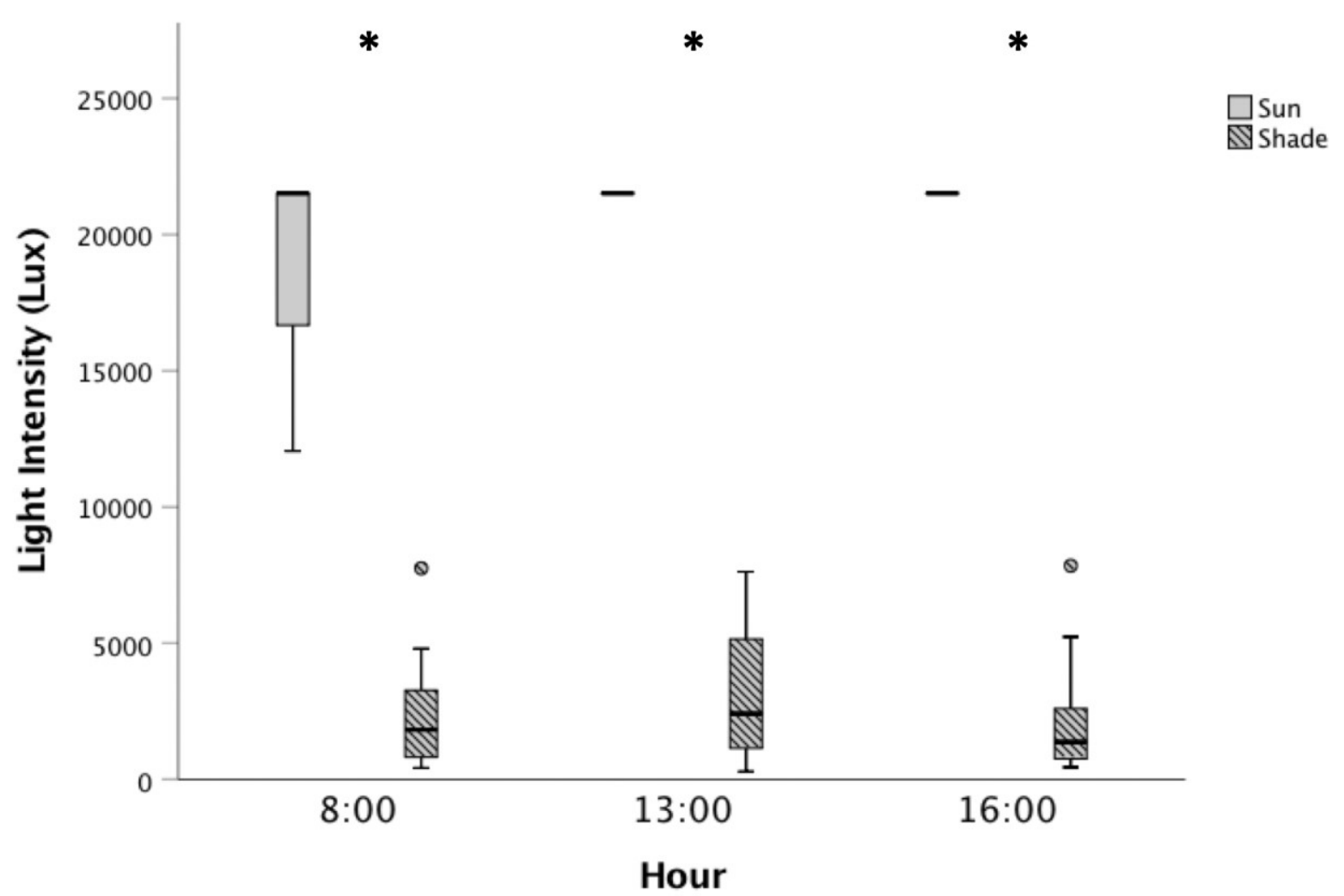

Figure 2 Boxplots displaying median light intensity (Lux) for sun and shade habitats during early, mid-, and late-day for all sites combined. Centre lines show the medians, boxes show interquartile range, and whiskers extend 1.5 times the interquartile range from the $25^{\text {th }}$ and $75^{\text {th }}$ percentiles. Asterisks within each panel indicates a significant difference in light intensity $(\mathrm{P}<0.05)$. Note: The light meter had a maximum reading of $\sim 21,500$ Lux (i.e. 2,000 Foot-candles), therefore measurements recorded in sun habitats shown above are likely smaller than the actual value. 


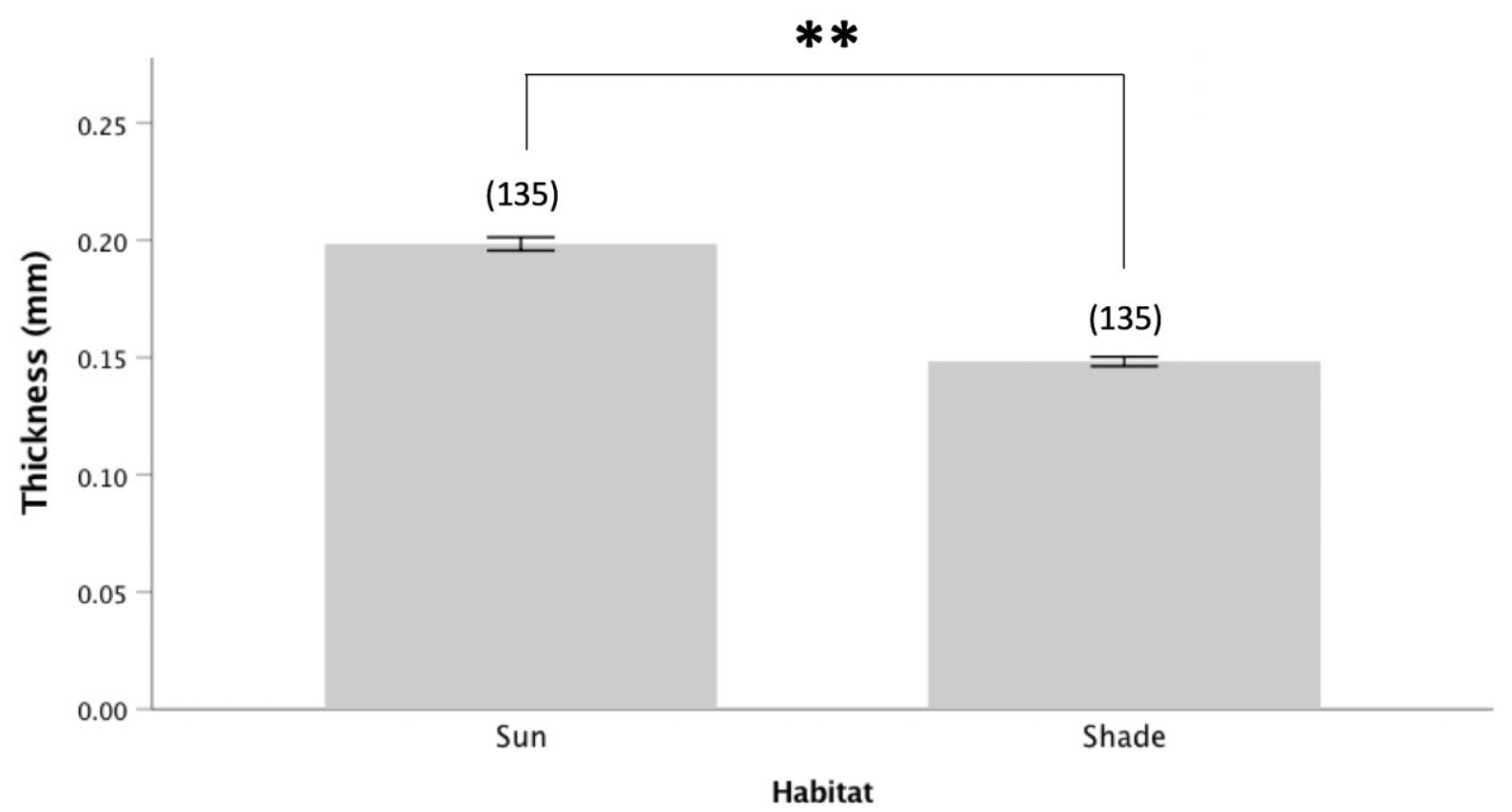

Figure 3 Mean \pm SE thickness $(\mathrm{mm})$ of Vincetoxicum rossicum leaves from sun and shaded habitats. Asterisks indicate significant differences in means between sun and shade foliage $(* *=<0.005)$. Sample sizes are given in parentheses. 


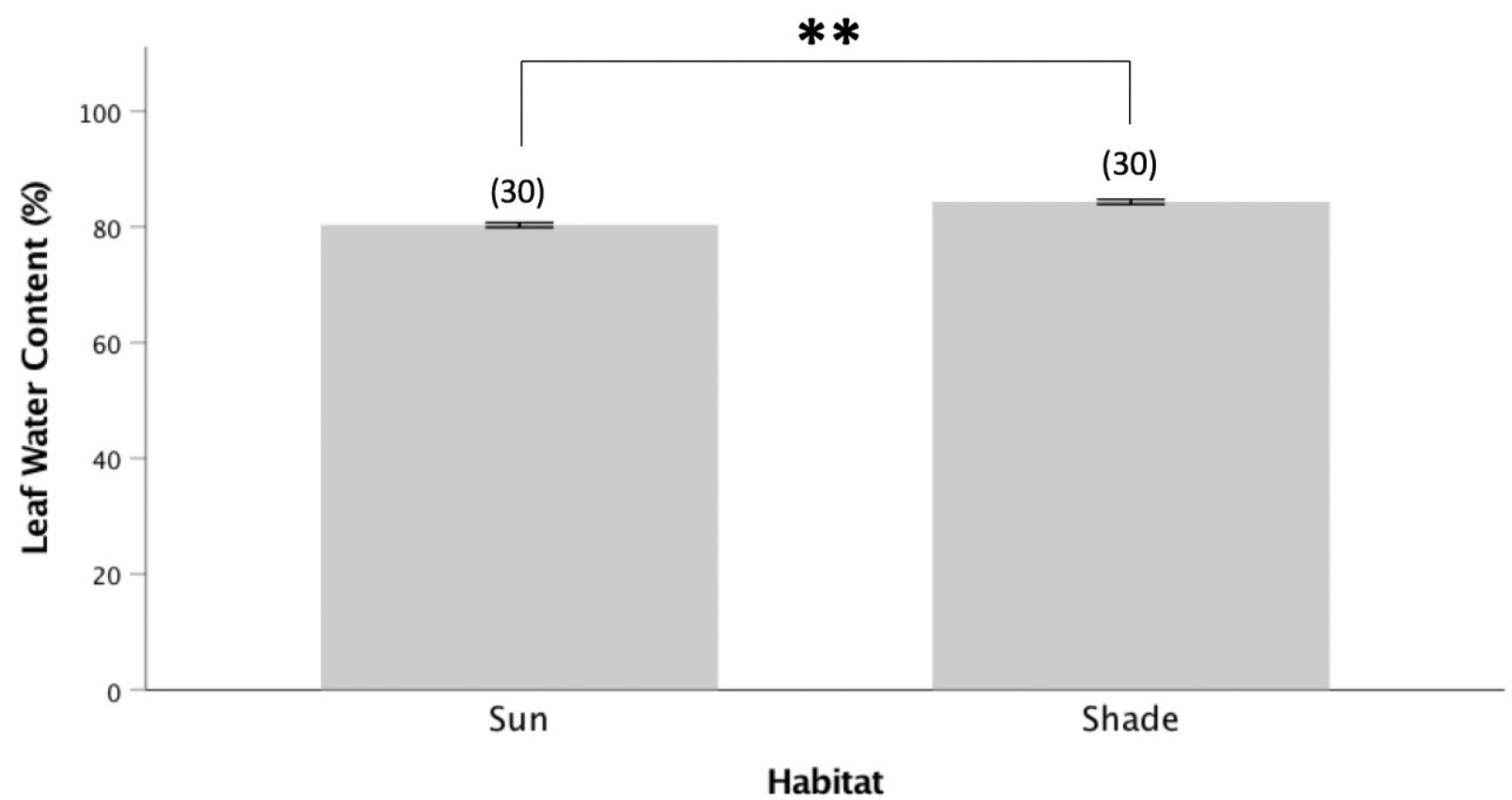

Figure 4 Mean \pm SE leaf water content (\%) of Vincetoxicum rossicum leaves from sun and shaded habitats. Asterisks indicate significant differences in means between sun and shade foliage $(* *=<0.005)$. Sample sizes are given in parentheses. 


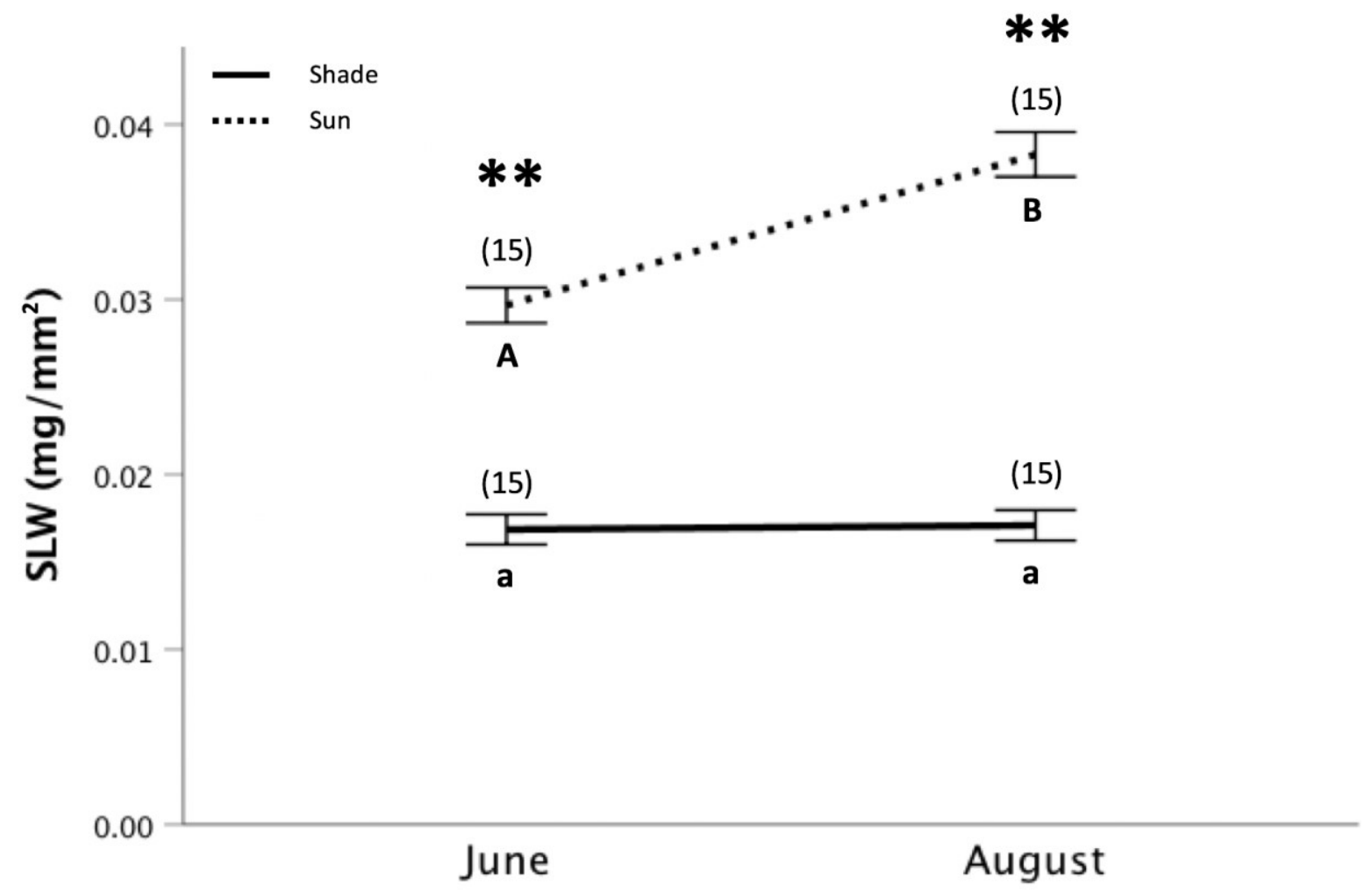

Figure 5 Mean \pm SE specific leaf weight $\left(\mathrm{mg} / \mathrm{mm}^{2}\right)$ for sun and shade Vincetoxicum rossicum leaves during June and August 2018. Asterisks indicate significant differences in means between sun and shade foliage $(* *=<0.005)$. Letters indicate significant differences in means between June and August for sun (uppercase) and shade (lowercase) foliage. Sample sizes are given in parentheses. 
Table 1 Summary of General Linear Model (GLM) (Habitat x Time x Month) on H. opulenta foliage consumption.

\begin{tabular}{lccccc}
\hline \hline Source & $\boldsymbol{d f}$ & MS & $\boldsymbol{F}$ & $\boldsymbol{p}$ & Effect Size \\
\hline Habitat & 1 & 13663.9 & 17.446 & $<0.0001$ & 0.068 \\
Time & 1 & 81038.1 & 103.47 & $<0.0001$ & 0.301 \\
Month & 2 & 12421.7 & 15.859 & $<0.0001$ & 0.117 \\
Habitat x Time & 1 & 3737.8 & 4.760 & 0.030 & 0.019 \\
Habitat x Month & 2 & 1318.2 & 1.683 & 0.188 & 0.014 \\
Time x Month & 2 & 4751.0 & 6.066 & 0.003 & 0.048 \\
Habitat x Time x Month & 2 & 555.0 & 0.709 & 0.493 & 0.006 \\
Error & 240 & 783.2 & - & - & - \\
\hline
\end{tabular}

Note. $-\mathrm{MS}=$ Mean squares, effect size $=$ partial $\eta^{2}$. 


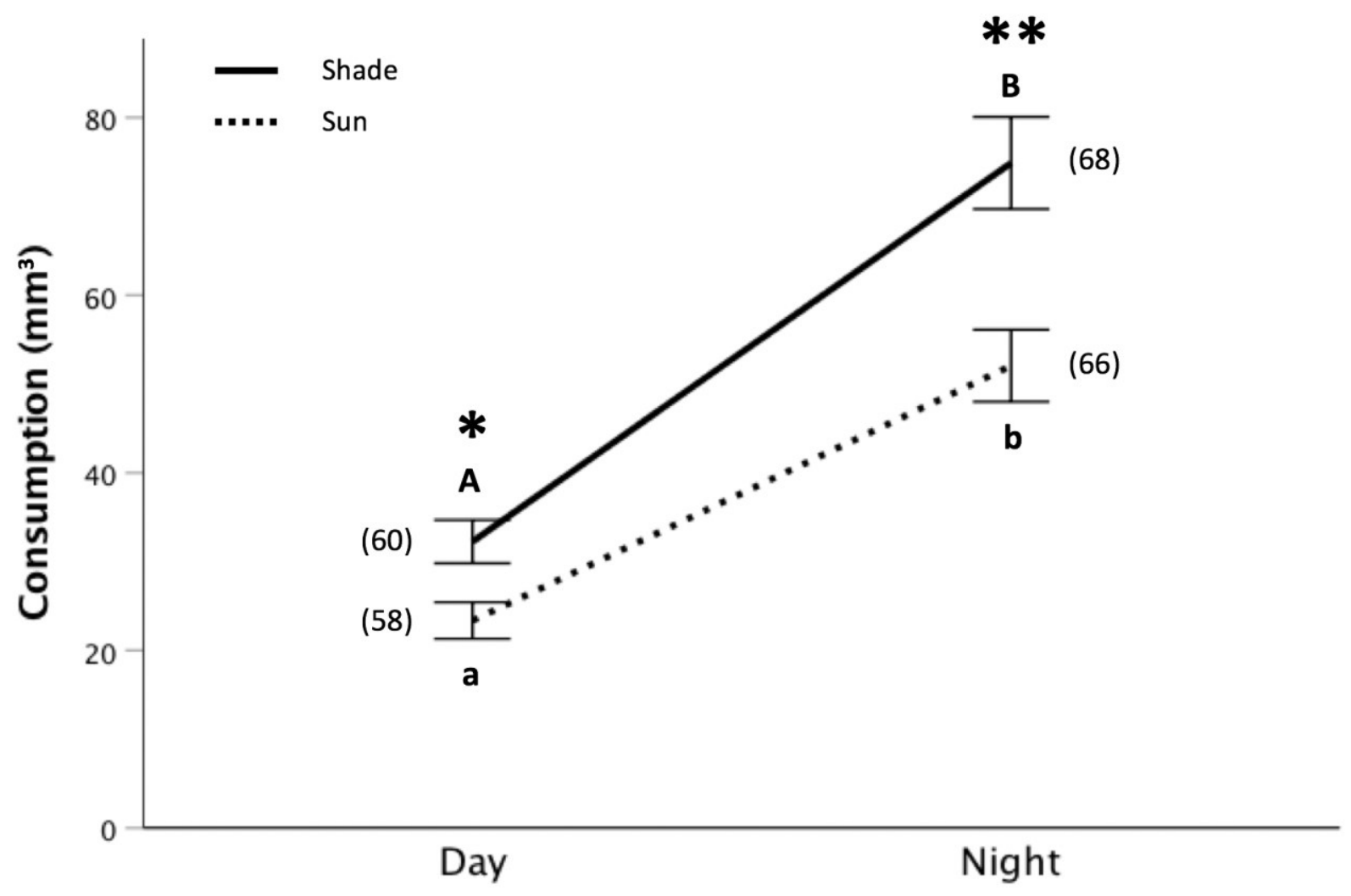

Figure 6 Mean \pm SE Vincetoxicum rossicum foliage consumption $\left(\mathrm{mm}^{3}\right)$ by Hypena opulenta larvae over a 12-hour feeding period. Larval foliage consumption was compared for larvae reared on shade and sun foliage diets, in addition to night and day feeding intervals. Asterisks indicate significant differences in means between sun and shade foliage consumption $\left({ }^{*}=<0.05\right.$, $* *=<0.005)$. Letters indicate significant differences in means between day and night for sun (lowercase) and shade (uppercase) foliage consumption. Sample sizes are given in parentheses. 


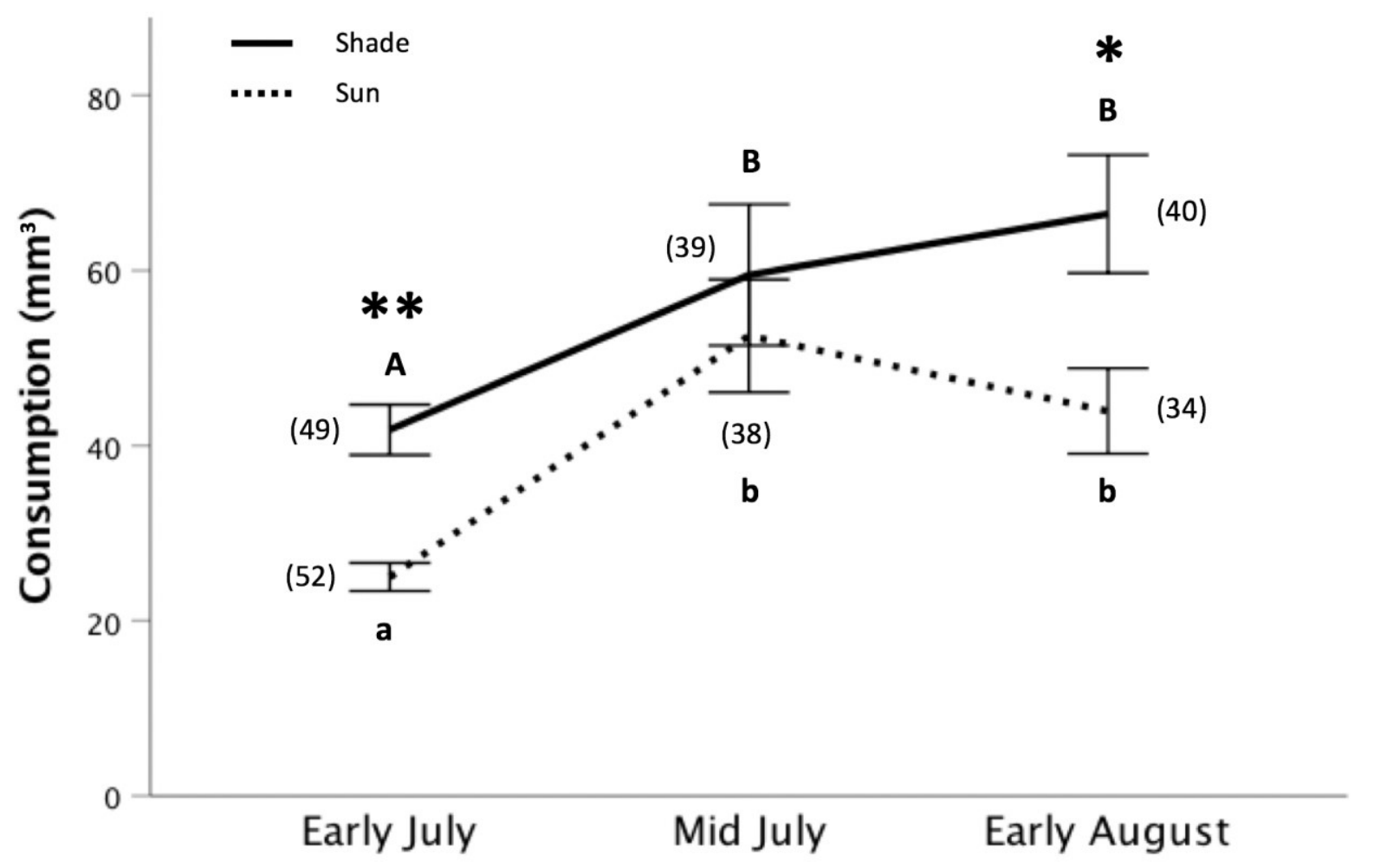

Figure 7 Mean \pm SE Vincetoxicum rossicum foliage consumption $\left(\mathrm{mm}^{3}\right)$ by Hypena opulenta larvae reared on sun or shade foliage over trials spanning from July to August. Asterisks indicate significant differences in means between sun and shade foliage consumption $\left({ }^{*}=<0.05\right.$, $* *=<0.005)$. Letters indicate significant differences in means between early July, mid-July, and early August for sun (lowercase) and shade (uppercase) foliage consumption (Bonferroni's tests: $\mathrm{P}<0.05)$. Sample sizes are given in parentheses. 


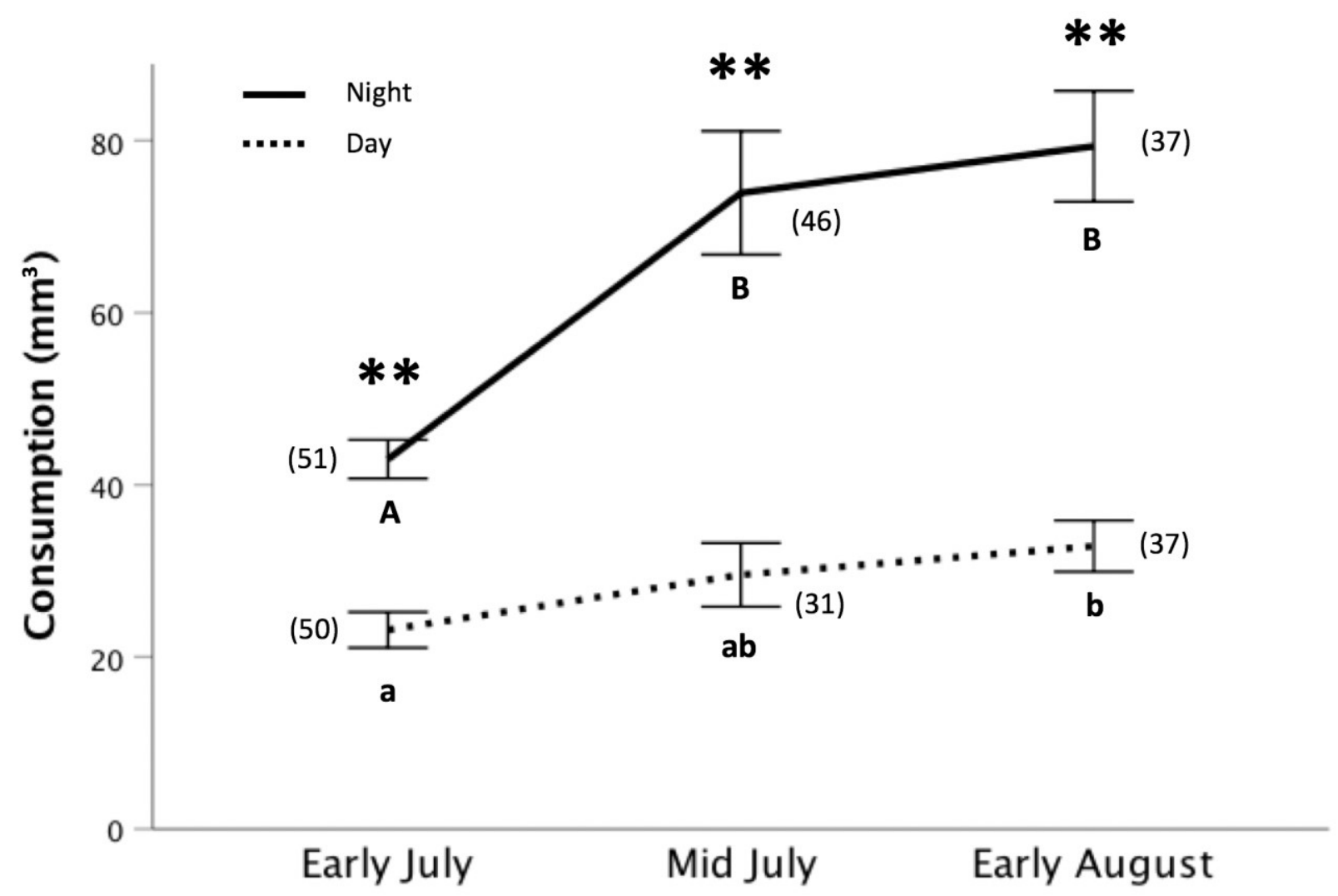

Figure 8 Mean \pm SE Vincetoxicum rossicum foliage consumption $\left(\mathrm{mm}^{3}\right)$ by Hypena opulenta larvae during day and night feeding intervals between July and August. Asterisks indicate significant differences in means between day and night foliage consumption $(* *=<0.005)$. Letters indicate significant differences in means between early July, mid-July, and early August for day (lowercase) and night (uppercase) foliage consumption (Bonferroni's tests: $P<0.05$ ). Sample sizes are given in parentheses. 


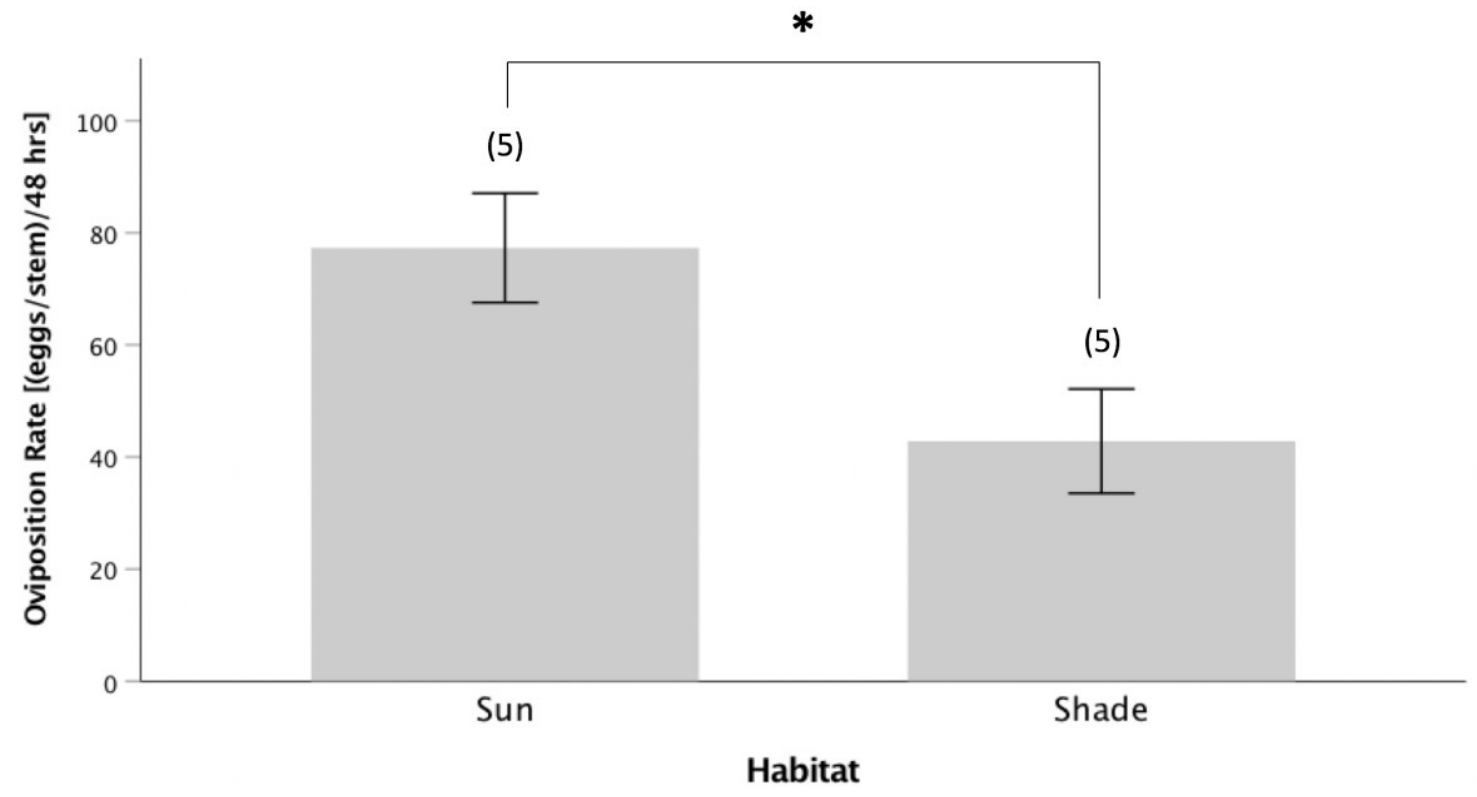

Figure 9 Mean \pm SE Oviposition rate [(eggs/stem)/48 hours] for Hypena opulenta with Vincetoxicum rossicum stems grown in full-sun and shaded habitats. Asterisks indicate means are significantly different $(P<0.05)$. Sample sizes are given in parentheses.

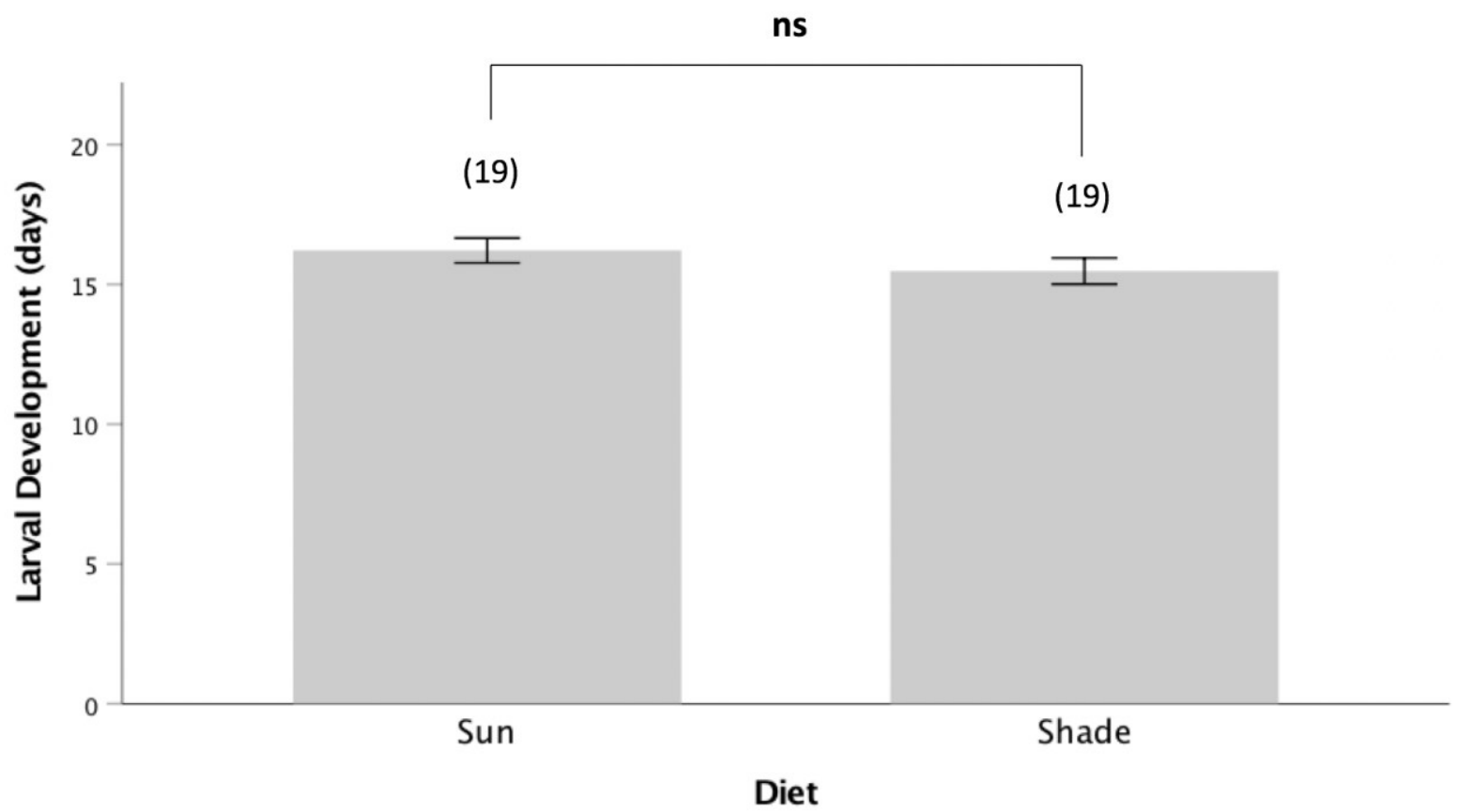

Figure 10 Mean \pm SE larval development rate (days), measured from first instar to pupation, of Hypena opulenta reared on sun and shade foliage diets. Sample sizes are given in parentheses. 


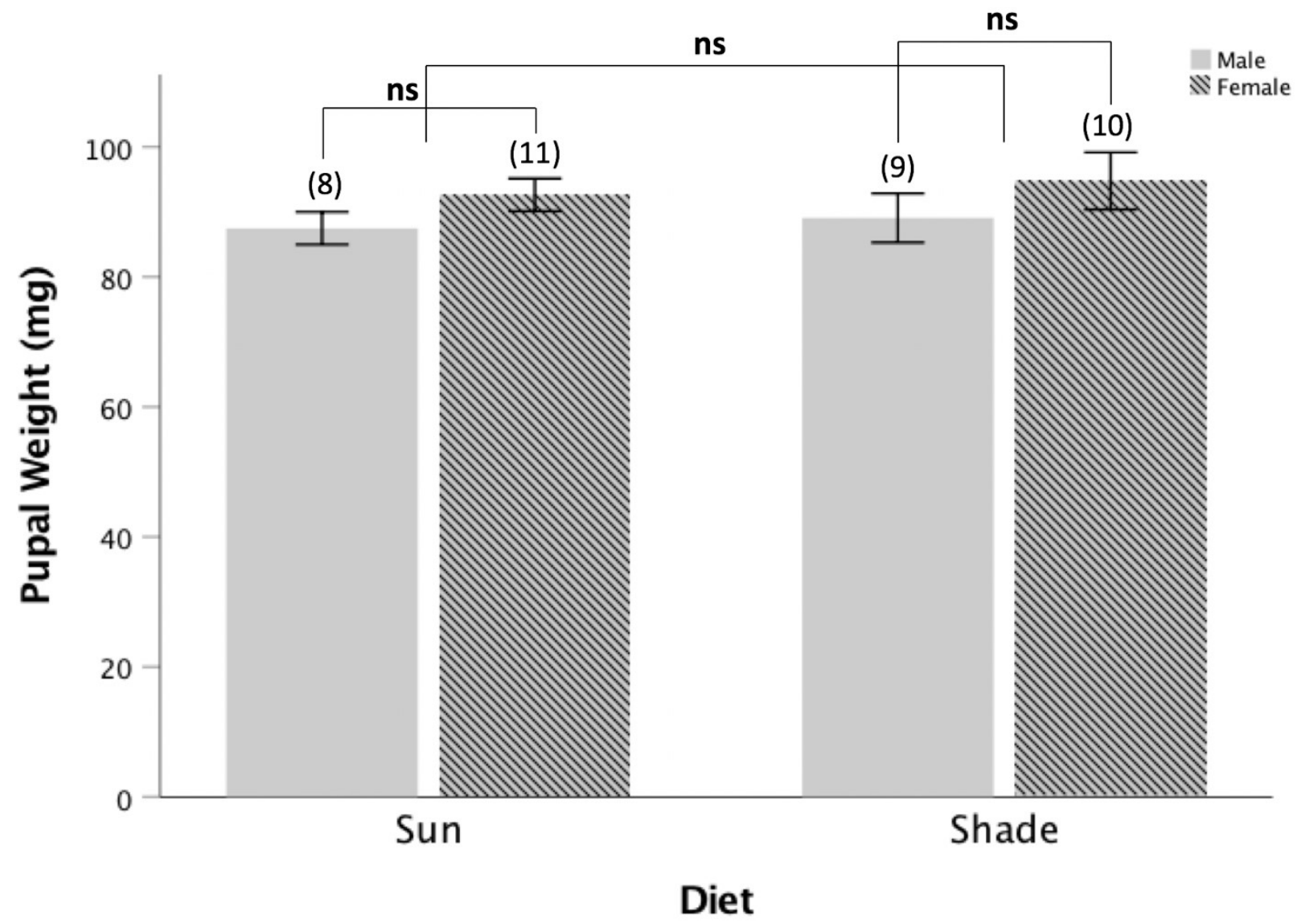

Figure 11 Mean \pm SE pupal weight $(\mathrm{mg})$ for male and female Hypena opulenta pupae reared on sun and shade foliage diets. Sample sizes are given in parentheses. 


\section{References}

Agosta, S.J. 2006. On ecological fitting, plant-insect associations, herbivore host shifts, and host plant selection. OIKOS 114: 556-565.

Amiri-Jami, A.R., H. Sadeghi, F. Gilbert, G. Moravvej \& A. Asoodeh. 2016. Oviposition preference of aphidophagous hoverflies toward oviposition site quality: the presence of intra- and interspecific competitor, glucosinolate content, and prey species. Journal of Asia-Pacific Entomology 19: 275280.

Averill, K.M., A. DiTommaso, C.L. Mohler \& L.R. Milbrath. 2010. Establishment of the invasive perennial Vincetoxicum rossicum across a disturbance gradient in New York State, USA. Plant Ecology 211: 65-77.

Banfield-Zanin, J.A. \& S.R. Leather. 2015. Season and drought stress mediate growth and weight of green spruce aphid on Sitka spruce. Agricultural and Forest Entomology 17: 48-56.

Barber, N.A. \& R.J. Marquis. 2011. Light environment and the impacts of foliage quality on herbivorous insect attack and bird predation. Oecologia 166: 401-409.

Berger, D. \& K. Gotthard. 2008. Time stress, predation risk and diurnal-nocturnal foraging trade-offs in larval prey. Behavioural Ecology and Sociobiology 62: 1655-1663.

Bisigato, A.J., C.L. Saín, M.V. Campanella \& G.H. Cheli. 2015. Leaf traits, water stress, and insect herbivory: is food selection a hierarchical process? Arthopod-Plant Interactions 9: 477-485.

Boege, K. \& R. Dirzo. 2004. Instraspecific variation in growth, defense and herbivory in Dialium guianense (Caesalpiniaceae) mediated by edaphic heterogeneity. Plant Ecology 175: 59-69.

Brunt, C., J. Read \& G. Sanson. 2006. Changes in resource concentration and defence during leaf development in a tough-leaved (Nothofagus moorei) and soft-leaved (Toona ciliate) species. Oecologia 148: 583-592.

Bryant, J.P., F.S. Chapin \& D.R. Klein. 1983. Carbon/nutrient balance of boreal plants in relation to vertebrate herbivory. OIKOS 40: 357-368.

Cappuccino, N. \& J.T. Arnason. 2006. Novel chemistry of invasive exotic plants. Biology Letters 2: 189193.

Carrington, L.B., M.V. Armijos, L. Lambrechts, C.M. Barker \& T.W. Scott. Effects of fluctuating daily temperatures at critical thermal extremes on Aedes aegypti life-history traits. PLOS ONE 8: e58824. 
Casagrande, R., A. Weed, A. Hazlehurst, L. Tewksbury, A. Gassman \& R. Bourchier. 2011. A petition for experimental open-field release of Hypena opulenta a potential biological control agent of swallow-worts (Vincetoxicum nigrum and V. rossicum) in North America. Submitted to the Canadian Biological Control Review Committee, CFIA and USDA-APHIS Technical Advisory Group for Biological Control of Weeds. http://web.uri.edu/biocontrol/files/2012/11/Hypena-ReleasePetition-Final-version-Nov-16-2011.pdf. Accessed December 4, 2018.

Coley, P.D. 1983. Herbivory and defensive characteristics of tree species in a lowland tropical forest. Ecological Monographs 53: 209-234.

Deas, J.B. \& M.S. Hunter. 2013. Delay, avoidance and protection in oviposition behaviour in response to fine-scale variation in egg parasitism risk. Animal Behaviour 86: 933-940.

Diamond, S.E. \& J.G. Kingsolver. 2010. Fitness consequences of host plant choice: a field experiment. OIKOS 119: 542-550.

DiTommaso, A., F.M. Lawlor \& S.J. Darbyshire. 2005. The biology of invasive alien plants in Canada. 2. Cyanchum rossicum (Kleopow) Borhidi [= Vincetoxicum rossicum (Kleopow) Barbar.] and Cyanchum louiseae (L.) Kartesz \& Gandhi [= Vincetoxicum nigrum (L.) Moench]. Canadian Journal of Plant Science 85: 243-263.

Dixit, G., A. Praveen, T. Tripathi, V.K. Yadav \& P.C. Verma. 2017. Herbivore-responsive cotton phenolics and their impact on insect performance and biochemistry. Journal of Asia-Pacific Entomology 20: 341-351.

Doubleday, L.A.D. \& N. Cappuccino. 2011. Simulated herbivory reduces seed production in Vincetoxicum rossicum. Botany 89: 235-242.

Ernst, C.M. \& N. Cappuccino. 2005. The effect of an invasive alien vine, Vincetoxicum rossicum (Asclepiadaceae) on arthropod populations in Ontario old fields. Biological Invasions 7: 417-425.

Feeny, P. 1970. Seasonal changes in oak leaf tannins and nutrients as a cause of spring feeding by winter moth caterpillars. Ecology 51: 565-581.

Fields, P., J.T. Arnason \& B.J. Philogène. 1989. Behavioural and physical adaptations of three insects that feed on the phototoxic plant Hypericum perforatum. Canadian Journal of Zoology 68: 339-346.

Friberg, M. \& C. Wiklund. 2016. Butterflies and plants: preference/performance studies in relation to plant size and the use of intact vs. cuttings. Entomologia Experimentalis et Applicata 160: 201 208.

Gripenberg, S., P.J. Mayhew, M. Parnell \& T. Roslin. 2010. A meta-analysis of preference-performa nce relationships in phytophagous insects. Ecology Letters 13: 383-393. 
Güzel, S., R. Pavela, A. Ilçim \& G. Kökdil. 2017. Phytochemical composition and antifeedant activity of five Vincetoxicum taxa against Spodoptera littoralis and Leptinotarsa decemlineata. Marmara Pharmaceutical Journal 21: 872-880.

Hazlehurst, A.F., A.S. Weed, L. Tewksbury \& R.A. Casagrande. 2012. Host-specificity of Hypena opulenta: a potential biological control agent of Vincetoxicum in North America. Environmental Entomology 41: 841-848.

Hou, J.L., W.D. Li, Q.Y. Zheng, W.Q. Wang, B. Xiao \& D. Xing. 2010. Effect of low light intensity on growth and accumulation of secondary metabolites in roots of Glycyrrhiza uralensis Fisch. Biochemical Systematics and Ecology 38: 160-168.

Hwang, S.Y. \& R.L. Lindroth. 1997. Clonal variation in foliar chemistry of aspen: effects on gypsy moths and forest tent caterpillars. Oecologia 111: 99-108.

Ingersoll, C.M., R.A. Niesenbaum, C.E. Weigle \& J.H. Lehman. 2010. Total phenolics and individual phenolic acids vary with light environment in Lindera benzoin. Botany 88: 1007-1010.

Jaenike, J. 1978. On optimal oviposition behaviour in phytophagous insects. Theoretical Population Biology 14: 350-356.

Johns, R.C., J. Boone, J.J. Leggo, S. Smith, D. Carleton \& D.T. Quiring. 2012. Temporal and spatial variations in microclimate influence the larval foraging behaviours and performance of a coniferfeeding sawfly. Environmental Entomology 41: 594-602.

Liang, K.M., Z.F. Lin, H. Ren, N. Liu, Q.M. Zhang, J. Wang, Z.F. Wang \& L.L. Guan. 2010. Characteristics of sun- and shade-adapted populations of an endangered plant Primulina tabacum Hance. Photosynthetica 48: 494-506.

Lindroth, R.L., K.A. Klein, J.D.C. Hemming \& A.M. Feuker. 1997. Variation in temperature and dietary nitrogen affect performance of the gypsy moth (Lymantria dispar L.). Physiological Entomology 22: 55-64.

Lowman, M.D. 1985. Temporal and spatial variability in insect grazing of the canopies of five Australian rainforest tree species. Australian Journal of Ecology 10: 7-24.

Malishev, M. \& G.D. Sanson. 2015. Leaf mechanics and herbivory defence: how tough tissue along the leaf body deters growing insect herbivores. Austral Ecology 40: 300-308.

Martins, C.H.Z., B.P. Cunha, V.N Solferini \& J.R. Trigo. Feeding on host plants with different concentrations and structures of pyrrolozidine alkaloids impacts the chemical-defense effectiveness of a specialist herbivore. PLOS ONE (10): e0141480. 
Mathur, S., L. Jain \& A. Jajoo. 2018. Photosynthetic efficiency in sun and shade plants. Photosynthetica 56: 354-365.

Mattson, W.J. 1980. Herbivory in relation to plant nitrogen content. Annual Review of Ecology and Systematics 11: 119-161.

Mazía N., E.J. Chaneton, C. Dellacanonica, L. Dipaolo \& T. Kitzberger. 2012. Seasonal patterns of herbivory, leaf traits, and productivity consumption in dry and wet Patagonian forests. Ecological Entomology 37: 193-203.

Milbrath L.R., A.S. Davis \& J. Biazzo. 2018. Identifying critical life stage transitions for biological control of long-lived perennial Vincetoxicum species. Journal of Applied Ecology 55:1465-1475.

Milbrath, L.R. \& J. Biazzo. 2016. Impact of the defoliating moth Hypena opulenta on invasive swallowworts (Vincetoxicum species) under different light environments. Biological Control 97: 1-12.

Milbrath, L.R. 2008. Growth and reproduction of invasive Vincetoxicum rossicum and V. nigrum under artificial defoliation and different light environments. Botany 86: 1279-1290.

Mogg, C., P. Petit, N. Cappuccino, T. Durst, C. McKague, M. Foster, J.E. Yack, J.T. Arnason \& M.L. Smith. Tests of the antibiotic properties of the invasive vine Vincetoxicum rossicum against bacteria, fungi and insects. Biochemical Systematics and Ecology 36: 383-391.

Müller, M.S., S.R. McWilliams, D. Podlesack, J.R. Donaldson, H.M. Bothwell \& R.L. Lindroth. 2006. Tritrophic effects of plant defenses: chickadees consume caterpillars based on host leaf chemistry. OIKOS 114: 507-517.

Osier, T.L. \& R.L. Lindroth. 2001. Effects of genotype, nutrient availability, and defoliation on aspen phytochemistry and insect performance. Journal of Chemical Ecology 27: 1289-1313.

Osier, T.L. \& S.M. Jennings. 2007. Variability in host-plant quality for the larvae of a polyphagous insect folivore in midseason: the impact of light on three deciduous sapling species. Entomologia Experimentalis et Applicata 123: 159-166.

Potter, K.A., J. Bronstein \& G. Davidowitz. 2012. Choice of oviposition sites by Manduca sexta and its consequences for egg and larval performance. Entomologia Experimentalis et Applicata 144: 286 293.

Raupp, M.J. 1985. Effects of leaf toughness on mandibular wear of the leaf beetle, Plagiodera versicolora. Ecological Entomology 10: 73-79.

Rausher, M.D. 1979. Egg recognition: its advantage to a butterfly. Animal Behaviour 27: 1034-1040. 
Refsnider, J. \& F. Janzen. 2010. Putting eggs in one basket: ecological and evolutionary hypotheses for variation in oviposition-site choice. Annual Review of Ecology, Evolution, and Systematics 41: 3957.

Riipi M., V. Ossipov, K. Lempa, E. Haukioja, J. Koricheva, S. Ossipova \& K. Pihlaja. 2002. Seasonal changes in birch leaf chemisty: are there trade-offs between leaf growth and accumulation of phenolics? Oecologia 130: 380-390.

Sarfraz R.M., H.M Kharouba \& J.H. Myers. 2013. Tent caterpillars are robust to variation in leaf phenology and quality in two thermal environments. Bulletin of Entomological Research 103: 522-529.

Shiojiri, K., M. Sabelis \& J. Takabayashi. 2015. Oviposition preference of cabbage white butterflies in the framework of costs and benefits of interspecific herbivore associations. Royal Society Open Science 2: 150524.

Simpson, S.J. \& J.D. Abisgold. 1985. Compensation by locusts for changes in dietary nutrients: behavioural mechanisms. Physiological Entomology 10: 443-452.

Slansky F. \& G.S. Wheeler. 1992. Caterpillar's compensatory feeding response to diluted nutrients leads to toxic allelochemical dose. Entomologia Experimentalis et Applicata 65: 171-186.

Smith, W.K. \& P.S. Nobel. 1977. Temperature and water relations for sun and shade leaves of a desert broadleaf, Hyptis emoryi. Journal of Experimental Botany 28: 169-183.

Steinbauer, M.J. 2001. Specific leaf weight as an indicator of juvenile leaf toughness in Tasmanian bluegum (Eucalyptus globulus ssp. globulus): implications for insect defoliation. Australian Forestry 64: 32-37.

Stoepler, T.M. \& B. Rehill. 2012. Forest habitat, not leaf phenotype, predicts late-season folivory of Quercus alba saplings. Functional Ecology 26: 1205-1213.

Stoepler, T.M. \& J.T. Lill. 2013. Direct and indirect effects of light environment generate ecological tradeoffs in herbivore performance and parasitism. Ecology 94: 2299-2310.

Tanton, M.T. 1962. The effect of leaf "toughness" on the feeding of larvae of the mustard beetle Phaedon cochleariae Fab. Entomologia Experimentalis et Applicata 5: 74-78.

Uyi, O.O., B.I. Uwagiahanor \& A.J. Ejomah. 2017. The nocturnal larvae of a specialist folivore prefer Chromolaena odorata (L.) foliage from a sunny environment, but does it matter? Arthropod-Plant Interactions 11: 603-611.

Uyi, O.O., C. Zachariades, L.U. Heshula \& M.P. Hill. 2018. Developmental and reproductive performance of a specialist herbivore depend on seasonality of, and light conditions experienced by, the host plant. PLOS ONE 13: e0190700. 
Wam, H.K., C. Stolter \& L. Nybakken. 2017. Compositional changes in foliage phenolics with plant age, a natural experiment in boreal forests. Journal of Chemical Ecology 43: 920-928.

Weed, A.S. \& R.A. Casagrande. 2010. Biology and larval feeding impact of Hypena opulenta (Christoph) (Lepidoptera: Noctuidae): a potential biological control agent for Vincetoxicum nigrum and $V$. rossicum. Biological Control 53: 214-222.

Weed, A.S., A. Gassmann, A.M. Leroux \& R.A. Casagrande. 2011. Performance of potential European biological control agents of Vincetoxicum spp. with notes on their distribution. Journal of Applied Entomology 135: 700-713.

Wiggins, N.L., D.L. Forrister, M.J. Endara, P.D. Coley \& T.A. Kursar. 2016. Quantitative and qualitative shifts in defensive metabolites define chemical defense investment during leaf development in Inga, a genus of tropical trees. Ecology and Evolution 6: 478-492.

Wyka, T.P., J. Oleksyn, R. Zytkowiak, P. Karolewski, A.M. Jagodzinski \& P.B. Reich. 2012. Responses of leaf structure and photosynthetic properties to intra-canopy light gradients: a common garden test with four broadleaf deciduous angiosperm and seven evergreen conifer tree species. Oecologia 170: 11-24.

Yang, L., K.S. Wen, X. Ruan, Y.X. Zhao, F. Wei \& Q. Wang. 2018. Response of plant secondary metabolites to environmental factors. Molecules 23: 762-788.

Zehnder, C.B., K.W. Stodola, B.L. Joyce, D. Egetter, R.J. Cooper \& M.D. Hunter. 2009. Elevational and seasonal variation in the foliar quality and arthropod community of Acer pensylvanicum. Environmental Entomology 38: 1161-1167.

Zhang, L.L. \& D.Z. Wen. 2009. Structural and physiological responses of two invasive weeds, Mikania micrantha and Chromolaena odorata, to contrasting light and soil water conditions. Journal of Plant Research 122: 69-79.

Zhang, L.L., Q.S. Guo, Q.S. Chang, Z.B. Zhu, L. Liu \& Y.H. Chen. 2015. Chloroplast ultrastructure, photosynthesis and accumulation of secondary metabolites in Glechoma longituba in response to irradiance. Photosynthetica 53: 144-153.

Zvereva, E.L. \& M.V. Kozlov. 2016. The costs and effectiveness of chemical defenses in herbivorous insects: a meta-analysis. Ecological Monographs 86: 107-124. 